University of Nebraska - Lincoln

DigitalCommons@University of Nebraska - Lincoln

\title{
Role of outer-membrane cytochromes MtrC and OmcA in the biomineralization of ferrihydrite by Shewanella oneidensis MR-1
}

\author{
C. L. Reardon \\ Pacific Northwest National Laboratory \\ Alice Dohnalkova \\ Pacific Northwest National Laboratory, alice.dohnalkova@pnl.gov \\ P. Nachimuthu \\ Pacific Northwest National Laboratory \\ David Kennedy \\ Pacific Northwest National Laboratory, david.kennedy@pnl.gov \\ D. A. Saffarini \\ University of Wisconsin \\ See next page for additional authors
}

Follow this and additional works at: https://digitalcommons.unl.edu/usdoepub

Part of the Bioresource and Agricultural Engineering Commons

Reardon, C. L.; Dohnalkova, Alice; Nachimuthu, P.; Kennedy, David; Saffarini, D. A.; Arey, B. W.; Shi, L.; Wang, Zheming; Moore, D.; Mclean, J. S.; Moyles, D.; Marshall, M. J.; Zachara, John M.; Fredrickson, James K.; and Beliaev, A. S., "Role of outer-membrane cytochromes MtrC and OmcA in the biomineralization of ferrihydrite by Shewanella oneidensis MR-1" (2010). US Department of Energy Publications. 265.

https://digitalcommons.unl.edu/usdoepub/265

This Article is brought to you for free and open access by the U.S. Department of Energy at DigitalCommons@University of Nebraska - Lincoln. It has been accepted for inclusion in US Department of Energy Publications by an authorized administrator of DigitalCommons@University of Nebraska - Lincoln. 


\section{Authors}

C. L. Reardon, Alice Dohnalkova, P. Nachimuthu, David Kennedy, D. A. Saffarini, B. W. Arey, L. Shi, Zheming Wang, D. Moore, J. S. Mclean, D. Moyles, M. J. Marshall, John M. Zachara, James K. Fredrickson, and A. S. Beliaev 


\title{
Role of outer-membrane cytochromes MtrC and OmcA in the biomineralization of ferrihydrite by Shewanella oneidensis MR-1
}

\author{
C. L. REARdON, ${ }^{1, *}$ A. C. DOHNALKOVA, ${ }^{1}$ P. NACHIMUTHU, ${ }^{1}$ D. W. KENNEDY, \\ D. A. SAFFARINI, ${ }^{2}$ B.W.AREY,${ }^{1}$ L. SHI,${ }^{1}$ Z.WANG,${ }^{1}$ D. MOORE, ${ }^{1}$ J. S. MCLEAN,${ }^{1, \dagger}$ D. MOYLES ${ }^{3}$ \\ M. J. MARSHALL, ${ }^{1}$ J. M. ZACHARA, ${ }^{1}$ J. K. FREDRICKSON ${ }^{1}$ AND A. S. BELIAEV ${ }^{1}$ \\ ${ }^{1}$ Biological Sciences Division, Pacific Northwest National Laboratory, Richland, WA, USA \\ ${ }^{2}$ Department of Biological Sciences, University of Wisconsin, Milwaukee, WI, USA \\ ${ }^{3}$ Department of Molecular and Cellular Biology, University of Guelph, Guelph, ON, Canada
}

\begin{abstract}
In an effort to improve the understanding of electron transfer mechanisms at the microbe-mineral interface, Shewanella oneidensis MR-1 mutants with in-frame deletions of outer-membrane cytochromes (OMCs), MtrC and OmcA, were characterized for the ability to reduce ferrihydrite (FH) using a suite of microscopic, spectroscopic, and biochemical techniques. Analysis of purified recombinant proteins demonstrated that both cytochromes undergo rapid electron exchange with $\mathrm{FH}$ in vitro with MtrC displaying faster transfer rates than OmcA. Immunomicroscopy with cytochrome-specific antibodies revealed that MtrC co-localizes with iron solids on the cell surface while OmcA exhibits a more diffuse distribution over the cell surface. After 3-day incubation of MR-1 with $\mathrm{FH}$, pronounced reductive transformation mineral products were visible by electron microscopy. Upon further incubation, the predominant phases identified were ferrous phosphates including vivianite $\left[\mathrm{Fe}_{3}\left(\mathrm{PO}_{4}\right)_{2} \cdot 8 \mathrm{H}_{2} \mathrm{O}\right]$ and a switzerite-like phase $\left[\mathrm{Mn}_{3}, \mathrm{Fe}_{3}\left(\mathrm{PO}_{4}\right)_{2} \cdot 7 \mathrm{H}_{2} \mathrm{O}\right]$ that were heavily colonized by MR-1 cells with surface-exposed outer-membrane cytochromes. In the absence of both MtrC and OmcA, the cells ability to reduce $\mathrm{FH}$ was significantly hindered and no mineral transformation products were detected. Collectively, these results highlight the importance of the outer-membrane cytochromes in the reductive transformation of $\mathrm{FH}$ and support a role for direct electron transfer from the OMCs at the cell surface to the mineral.
\end{abstract}

Received 25 June 2009; accepted 20 October 2009

Corresponding authors: Alex S. Beliaev. Tel.: (509) 371 6966; fax: (509) 371 6946; e-mail: alex.beliaev@pnl.gov; James K. Fredrickson. Tel.: (509) 376 7063; fax: (509) 3769650; e-mail: jim.fredrickson@pnl.gov

\section{INTRODUCTION}

Microbe-mineral interactions are central to biogeochemistry and the fundamental element cycling processes that shape the geology of our planet. Among these are reactions driving the redox-dependent transformations of metal ions catalyzed by a diverse group of dissimilatory metal reducing bacteria (DMRB). DMRB couple the oxidation of organic matter or $\mathrm{H}_{2}$ to the reduction of $\mathrm{Fe}(\mathrm{III})$ and are important catalysts in the linked cycling of carbon and metals in the environment. At circumneutral $\mathrm{pH}, \mathrm{Fe}(\mathrm{III})$ oxides are poorly soluble (Cornell

*Present address: U.S. Department of Agriculture-Agricultural Research Service Tree Fruit Research Laboratory, Wenatchee, WA, USA

†Present address: The J. Craig Venter Institute, La Jolla, CA, USA
\& Schwertmann, 1996) therefore constraining the reduction rates, to a large degree, by physical limitations imposed by the solid surface. The reduction of $\mathrm{Fe}$ (III)-containing minerals is complex and influenced by mineral properties including composition, degree of crystallinity and crystal disorder, microheterogeneities, surface area, and free energy constraints (Zachara et al., 1998; Neal et al., 2003; Hansel et al., 2004).

The most bioavailable iron oxides are those forms with either low crystallinity [e.g., ferrihydrite (FH)] or higher crystallinity but nanometer sizes (e.g., goethite, lepidocrocite) (Hansel et al., 2004). Changes to iron minerals as a result of microbial reduction, termed reductive transformation, include (i) dissolution of surface layers or structural regions via $\mathrm{Fe}$ (II) generation (Rosso et al., 2003), (ii) recrystallization of more stable $\mathrm{Fe}$ (III)-oxides (Zachara et al., 2002; Hansel et al., 2003), and (iii) biotransformation to mixed $\mathrm{Fe}(\mathrm{II}) /$ 
$\mathrm{Fe}(\mathrm{III})$ or $\mathrm{Fe}(\mathrm{II})$ mineral phases (Fredrickson et al., 1998; Zachara et al., 2002; Hansel et al., 2003). The nature of the secondary mineral phases is dependent on a range of factors not limited to medium composition (phosphate and/or carbonate concentration, $\mathrm{pH}$ ), cell density, rate of $\mathrm{Fe}(\mathrm{II})$ generation, nature and concentration of electron donor, and mineral substrate preparation (Fredrickson et al., 1998; Kukkadapu et al., 2004; Borch et al., 2007).

One of the grand challenges of geomicrobiology is to understand mechanistically the electron transfer processes driving the reductive transformations at the microbe-mineral interface (Fredrickson \& Zachara, 2008). This has proven to be an exceptionally difficult region to probe experimentally as the reactions mediated at the interface are probably regulated by both biological mechanisms of adhesion [i.e., proteins, lipopolysaccharides, extracellular polymeric substances (EPS), etc.] and chemical reactions (i.e., redox-active proteins and protein complexes, ligands, electron mediators). Multiple mechanisms for extracellular electron transfer to solids by DMRB have been proposed, but the pathways are poorly understood and few quantitative relationships are established [reviewed in (Gralnick \& Newman, 2007)]. Numerous studies have implicated $c$-type cytochromes in extracellular electron transfer processes in Shewanella and Geobacter spp. (Beliaev \& Saffarini, 1998; Myers \& Myers, 1998; Beliaev et al., 2001; Magnuson et al., 2001; Leang et al., 2003; Mehta et al., 2005). For example, Shewanella oneidensis MR1 has been shown to mediate terminal electron transfer to minerals both directly by redox-active proteins (Myers \& Myers, 1992, 2001, 2003a; Beliaev \& Saffarini, 1998) and indirectly through soluble shuttle molecules (Lovley et al., 1996; Newman \& Kolter, 2000; Turick et al., 2002; Taillefert et al., 2007; von Canstein et al., 2008; Marsili et al., 2008; Ross et al., 2009). Several recent studies have also proposed an involvement of electrically conductive pilus-like appendages in the extracellular transfer of electrons by $S$. oneidensis MR-1 (Gorby et al., 2006; El-Naggar et al., 2008) and Geobacter sulfurreducens (Reguera et al., 2005).

Central to the extracellular electron transfer is the outermembrane localization of high-molecular weight $c$-type cytochromes, a feature unique to many DMRB including Shewanellae (Shi et al., 2007). In S. oneidensis MR-1, two decaheme $c$-type cytochromes, MtrC and OmcA, which contain externally exposed domains (Myers \& Myers, 2003b, 2004) and are capable of in vitro electron transfer to soluble metal species (Xiong et al., 2006; Wang et al., 2008; Ross et al., 2009) and radionuclides (Marshall et al., 2006, 2008), have been implicated in dissimilatory metal reduction. MtrC and OmcA are encoded within the $\operatorname{omc} A-m \operatorname{tr} C A B$ cluster of genes, which constitute the principle components of the metal reductase system (Beliaev \& Saffarini, 1998; Myers \& Myers, 1998; Beliaev et al., 2001). To better understand the role of these proteins in electron transfer at the cell-mineral interface, complimentary analyses were used to determine whether the outer-membrane cytochromes (OMCs), which reduce $\mathrm{FH}$ in vitro, are required for reductive biotransformation in vivo, and are in direct contact with $\mathrm{FH}$ during reductive transformation. This study demonstrates the requirement of at least one of the cytochromes, MtrC or OmcA, for $\mathrm{FH}$ reduction and biotransformation. Consistent with their role in direct electron transfer is the localization of MtrC and OmcA at the outer membrane in proximity to membrane-associated $\mathrm{FH}$ aggregates.

\section{MATERIALS AND METHODS}

\section{Bacterial strains and growth conditions}

Shewanella oneidensis MR-1 cytochrome deletion mutants, $\Delta m t r C, \Delta o m c A, \Delta m t r C-\Delta o m c A$, are described in a previous study (Marshall et al., 2006, 2008). Shewanella oneidensis MR-1 wild-type and mutant strains were routinely cultured in dextrose-free trypticase soy broth (TSB) or Luria-Bertani media at $30{ }^{\circ} \mathrm{C}$. For growth and metal reduction assays, cells were cultured in Ml-defined medium ( $\mathrm{pH}$ 7.2) that contained: $30 \mathrm{~mm}$ PIPES, $7.5 \mathrm{~mm} \mathrm{NaOH}, 28 \mathrm{~mm} \mathrm{NH}_{4} \mathrm{Cl}$, $1.34 \mathrm{~mm} \mathrm{KCl}, 4.35 \mathrm{~mm} \mathrm{NaH}{ }_{2} \mathrm{PO}_{4}, 30 \mathrm{~mm} \mathrm{NaCl}, 3 \mathrm{~mm}$ $\mathrm{MgCl}_{2} \cdot 6 \mathrm{H}_{2} \mathrm{O}$ and $10 \mathrm{~mL} \mathrm{~L}^{-1}$ each of amino acid, $\left(2 \mathrm{~g} \mathrm{~L}^{-1}\right.$ L-arginine hydrochloride, $2 \mathrm{~g} \mathrm{~L}^{-1}$ L-glutamate, $2 \mathrm{~g} \mathrm{~L}^{-1}$ L-serine), Wolfe's vitamin solution and trace mineral mixture containing $0.25 \mathrm{~g} \mathrm{~L}^{-1} \quad \mathrm{NiCl}_{2} \cdot 6 \mathrm{H}_{2} \mathrm{O}$ and $\mathrm{Na}_{2} \mathrm{WO}_{4} \cdot 2 \mathrm{H}_{2} \mathrm{O}$ (Lovley et al., 1984). After autoclave sterilization, the medium was supplemented with $1 \mu \mathrm{M} \mathrm{Na} \mathrm{Na}_{2} \mathrm{SeO}_{4}, 0.05 \mu \mathrm{M}$ Fe(III)-NTA. For microscopy studies, the PIPES buffer system was substituted with $20 \mathrm{~mm}$ HEPES. Sodium lactate was added as the electron donor for all cultures at a final concentration of $20 \mathrm{~mm}$. During aerobic growth, $\mathrm{O}_{2}$ served as the only electron acceptor. When noted, filter-sterilized soluble iron or non-sterilized insoluble iron and manganese oxides were added as terminal electron acceptors.

\section{Immunolocalization studies}

The localization of MtrC and OmcA was determined using epifluorescence and transmission electron microscopy (TEM) of $S$. oneidensis MR-1 cells incubated with $\mathrm{FH}$ or $\mathrm{Fe}(\mathrm{III})$ citrate. All immunolabeling experiments were carried out sideby-side with the $\Delta m t r C-\Delta o m c A$ strain as a negative control for the labeling pattern or intensity. In all experiments, there was little specific labeling with the $\Delta m t r C-\Delta o m c A$ mutant or the pattern of labeling was uncharacteristic to that of MR-1 cells.

Cells were cultured either anaerobically for 3 days in Ml-defined medium supplemented with $5 \mathrm{~mm} \mathrm{FH}$ or aerobically on $10 \mathrm{~mm} \mathrm{Fe}$ (III)-citrate-supplemented basal medium plates containing $60 \mathrm{~mm}$ HEPES, $50 \mathrm{~mm}$ lactate, trace metals and minerals, and 1.5\% agar (O'Connell, 2007). The TEM and epifluorescent immunolocalization of MtrC and OmcA using cells incubated on $\mathrm{Fe}$ (III)-citrate plates was 
performed similarly on either formvar/carbon-coated 200 mesh $\mathrm{Cu}$ electron microscopy grids (Electron Microscopy Sciences, Hatfield, PA, USA) or poly-L-lysine-coated glass slides according to a previously published protocol (Braun \& McBride, 2005). Briefly, cells were gently resuspended in Ml-defined medium, transferred to EM grids or slides, incubated for $5 \mathrm{~min}$ for adhesion and fixed with $1 \%$ paraformaldehyde (PFA) for $15 \mathrm{~min}$. Cells were washed $1 \times$ with phosphate-buffered saline (PBS) ( $\mathrm{pH}$ 7.4) and TEMprepared cells were treated with $0.05 \mathrm{M}$ glycine for $20 \mathrm{~min}$ to quench free aldehyde groups. After an additional PBS wash, cells were incubated with blocking solution (1\% Fraction V BSA/PBS solution with $0.02 \% \mathrm{Na}$-azide), and reacted with primary antibody diluted in blocking solution for either $2 \mathrm{~h}$ at room temperature or overnight at $4{ }^{\circ} \mathrm{C}$ for epifluorescence or EM imaging, respectively. Cells were washed $3 \times$ with PBS and incubated with either anti-rabbit secondary antibody conjugated to Alexa Fluor 488 dye (Molecular Probes, Carlsbad, CA, USA) or 5-nm gold-conjugated secondary antibody (Sigma-Aldrich, St. Louis, MO, USA). In an effort to dissolve the iron solids on the cell surface, cells were extracted with an oxalic acid solution $\left(15 \mathrm{~g} \mathrm{~L}^{-1}, \mathrm{pH} 3.0\right)$ for $15 \mathrm{~min}$ at room temperature between the first two PBS wash steps following the fixation (Roden \& Zachara, 1996). Cells prepared for epifluorescence were counterstained with 4',6-diamidino2-phenylindole (DAPI) (Molecular Probes) and viewed with a Nikon Eclipse 50i (Nikon USA, Melville, NY, USA) equipped with a Photometrics CoolSNAP ES camera. Pseudo-colored images were optimized for contrast and superimposed using either Image (NIH, Bethesda, MD, USA; http://rsb.info.nih.gov/ij) or Adobe Photoshop CS3 software (Adobe Systems Incorporated, San Jose, CA, USA). TEM was performed with a Hitachi H-600 TEM electron microscope (Hitachi, Tokyo, Japan) operated at $75 \mathrm{kV}$.

Immunolocalizations with $\mathrm{FH}$-incubated cells were carried out similar to $\mathrm{Fe}$ (III)-citrate incubated cells with the following exceptions. The cells were fixed with a $2 \%$ PFA and $1 \%$ gluteraldehyde solution for $15 \mathrm{~min}$, primary antibody incubation was performed overnight at $4{ }^{\circ} \mathrm{C}$ on a PTFE immuno-staining tray (Ted Pella, Redding, CA, USA) in a humid chamber, and the final washing protocol following the secondary antibody incubation was five PBS washes, 5 -min fixation in $2.5 \%$ gluteraldehyde (diluted in PBS) followed by two PBS washes and two final washes with $\mathrm{H}_{2} \mathrm{O}$.

Immunolocalization of MtrC on mineral-associated cells was performed similar to the epifluorescence protocol described above. Mineral phases collected from 11-day $\mathrm{FH}$ incubations with MR-1 and $\Delta m t r C-\Delta o m c A$ were transferred to microcentrifuge tubes and fixed with $4 \%$ PFA. All washes were performed in-tube as $1.5 \mathrm{~mL}$ volume exchanges and antibodies were added as $50 \mu \mathrm{L}$ aliquots. The cells were counterstained with Syto 60 (Invitrogen, Carlsbad, CA, USA) and imaged using a Leica TCSP2 Scanning Confocal Laser Microscope (Leica Microsystems Inc., Bannockburn,
IL, USA) with either $40 \times$ or $63 \times$ water immersion objectives. Image stacks were compiled into simulated 3-D images using the Volocity software (Improvision, Waltham, MA, USA).

Thin sections of unfixed cells were used to preserve the physical state of the native microbe-mineral architecture. FH-incubated cells were prepared for cryo-sections with high-pressure freezing, freeze substitution and cryoembedding at $-50{ }^{\circ} \mathrm{C}$ in Lowicryl HM20 followed by UV polymerization. Cells were harvested from 3 -day incubations by brief centrifugation with a quick-spin minifuge and approximately $3 \mu \mathrm{L}$ of the suspension was transferred to a flat specimen carrier and frozen with Leica EM PACT2 high-pressure freezer (Leica Microsystems Inc.). The frozen sample was transferred under liquid nitrogen to the Leica EM AFS2 automatic freeze substitution system (Leica Microsystems Inc.) and treated with an immuno-cytochemical sample preparation protocol modified from previously published techniques (Skepper, 2000). Briefly, the water in the form of ice was substituted with $100 \%$ acetone and $0.1 \%$ glutaraldehyde at $-180{ }^{\circ} \mathrm{C}$ for $72 \mathrm{~h}$. The acetone was replaced three times over the next $24 \mathrm{~h}$ in which the sample was warmed to $-50{ }^{\circ} \mathrm{C}$. The cells were infiltrated with a 50:50 mixture of 100\% acetone and Lowicryl HM20 for $4 \mathrm{~h}$ before impregnating with three changes of $100 \%$ Lowicryl HM20 resin over a 24 -h period. The resin was polymerized by UV irradiation for $48 \mathrm{~h}$ at $-50{ }^{\circ} \mathrm{C}$, slowly brought to room temperature and cured for an additional $24 \mathrm{~h}$ with UV light. The polymerized blocks were sectioned using a Leica Ultracut UCT ultramicrotome (Leica Microsystems GmbH, Wetzlar, Germany) to $100-\mathrm{nm}$ thin sections, mounted on TEM grids and treated identical to the whole mounts with the exception that all washes were carried out with PBS supplemented with $0.01 \%$ Tween-20. Sections jointly labeled for polysaccharides included a $1: 10$ dilution of 30-nm gold-conjugated concanavalin A (ConA; EY Laboratories, San Mateo, CA, USA) in the secondary antibody incubation step. Sections were post-stained for $7 \mathrm{~min}$ with 1\% uranyl acetate followed by 3 min with Reynolds' lead citrate (Reynolds, 1963) prior to scoping. In an attempt to preserve the cell-mineral interactions, EM grids were mounted on Aclar Fluoropolymer film (SPI Supplies, West Chester, PA, USA), incubated in the culture tube, collected and air-dried before viewing. TEM was performed using a Tecnai T-12 high-resolution TEM equipped with a LaB6 filament operating at $120 \mathrm{kV}$ (FEI, Hillsboro, OR, USA). Images were digitally collected and analyzed using DigitalMicrograph software (Gatan Inc., Pleasanton, CA, USA). The gold labels were pseudo-colored for enhanced viewing using Photoshop CS3 software.

\section{Analysis of mineral transformation}

To visualize the association of the cells, FH and secondary mineral phases, 3- and 11-day incubations of MR-1 with 
$5 \mathrm{~mm}$ FH were analyzed by TEM, scanning electron microscopy (SEM), and/or micro-X-ray diffraction (micro-XRD). For TEM analysis, unfixed cells from 3- and 11-day cultures were transferred aerobically to TEM grids, briefly air-dried and immediately imaged with high-resolution TEM. For cryo-SEM analysis of the same 11-day culture imaged by TEM, cells were transferred aerobically to a TEM grid, which was adhered by carbon tape to an aluminum stub on the cold stage, immediately plunge frozen into liquid $\mathrm{N}_{2}$ and transferred to the cryo-stage. The sample was sublimated at $-95{ }^{\circ} \mathrm{C}$ for $5 \mathrm{~min}$ and cooled to $-160{ }^{\circ} \mathrm{C}$ before platinum coating. The sample was imaged at $-180^{\circ} \mathrm{C}$ at $5 \mathrm{kV}$ on an FEI Helios NanoLab 600 Dual Beam microscope (FEI, Hillsboro, OR, USA) with a quorum cryo-stage. Electron dispersive spectroscopy (EDS) was performed on dehydrated samples at $20 \mathrm{keV}$ with a count time of 100 live seconds and an approximately $20-30 \%$ deadtime. The spectra were analyzed with Oxford INCA software (Oxford Instruments, Oxfordshire, UK) for the EDS.

The mineral phases associated with MR-1 after 11-day incubations as imaged by SEM and TEM analysis were identified by micro-XRD using either a single mineral precipitate or total hydrated cell suspension. The large size of some of the transformation products (up to $60 \mu \mathrm{m}$ ) aided the mounting of a single particle on a glass fiber with quick set epoxy. The particle was mounted under aerobic conditions, transferred immediately to the diffractometer and analyzed at three different areas. All manipulations of samples for analysis of the total suspension were carried out in an anaerobic chamber. To analyze the bulk phase, the entire culture volume was harvested at $10000 \mathrm{~g}$, concentrated in approximately $50-100 \mu \mathrm{L}$, loaded into skirted, closed bottom quartz $0.8 \mathrm{~mm}$ OD $\times 80 \mathrm{~mm}$ length capillary tubes with $0.01-\mathrm{mm}$ wall thickness (Hampton Research, Aliso Viejo, CA, USA). The capillary tubes were centrifuged at $5000 \mathrm{~g}$ for $5 \mathrm{~min}$, broken to approximately one to two inches in length and sealed with beeswax. Four diffractograms were collected along the length of the capillary. All X-ray diffraction measurements were collected with a Rigaku D/MAX RAPID II microdiffractometer (Rigaku Corporation, Tokyo, Japan) with a curved imaging plate and a rotating $\mathrm{Cr}$ anode operating at $35 \mathrm{kV}$ and $25 \mathrm{~mA}$. Diffraction data were analyzed using JADE 8.5 from Materials Data Inc. (Livermore, CA, USA) and whole pattern fitting was used for semi-quantification of the phases.

\section{Preadsorption of antibodies}

Affinity-purified antibodies were produced against MtrC (Beliaev et al., 2001), and OmcA (Shi et al., 2008). In initial experiments, the traditional 'no antibody' control proved to be insufficiently stringent for EM-immunolocalizations as there was significant labeling of $\Delta m \operatorname{tr} C-\Delta o m c A$ but not wild-type cells lacking the primary antibody.
Although the antibodies were affinity purified and western blotting did not indicate any non-specific binding to other proteins, several blocking solutions and protocols were tested and optimized to reduce labeling in $\Delta m t r C$ $\Delta o m c A$. Pre-adsorption of the antibodies to the mutant lysate $(\Delta m t r C$ or $\Delta o m c A)$ removed non-specific epitopebinding antibodies such that the patterns or intensity of label was distinguishable between single cells of the wildtype and $\Delta m t r C-\Delta o m c A$ imaged by EM. Briefly, antibodies were diluted $1: 10$ in filter-sterilized PBS containing $1 \%$ Fraction V BSA and $0.02 \%$ sodium azide and incubated overnight at $4{ }^{\circ} \mathrm{C}$ with total protein extracts from the mutant strains bound to nitrocellulose membranes $(\Delta m t r C$ and $\Delta o m c A)$. The solution containing the unbound antibody was filter-sterilized and stored at $4{ }^{\circ} \mathrm{C}$.

\section{Metal reduction assays}

The kinetics of $\mathrm{Fe}(\mathrm{III})$ and $\mathrm{Mn}(\mathrm{IV})$ reduction by $S$. oneidensis MR-1 wild-type and mutant strains were determined under growth conditions with synthetic silica-FH (2\% Si) (Kukkadapu et al., 2004), Fe(III)-citrate, or Fe(III)-NTA. Aliquots (1 mL) of aerobically grown TSB cultures were transferred to defined medium $(50 \mathrm{~mL}$ in a $125-\mathrm{mL}$ flask $)$ and incubated overnight at $30{ }^{\circ} \mathrm{C}$ with $150 \mathrm{rpm}$ shaking. The pre-grown cells were purged with $\mathrm{N}_{2}$ and transferred at a final $\mathrm{OD}_{600}$ of 0.075 (representing c. $1 \times 10^{8}$ cells $\mathrm{mL}^{-1}$ ) to Balch tubes containing $10 \mathrm{~mL}$ of anaerobic PIPES-buffered Ml medium supplemented with $20 \mathrm{~mm}$ sodium lactate and $10 \mathrm{~mm} \mathrm{FH}$, $\mathrm{Fe}(\mathrm{III})$-citrate, or Fe(III)-NTA. Cultures were incubated horizontally at $30^{\circ} \mathrm{C}$ with $25 \mathrm{rpm}$ shaking. $\mathrm{Fe}$ (III) reduction was monitored by overnight extraction of samples with $0.5 \mathrm{~N}$ $\mathrm{HCl}$ and quantification of total $\mathrm{Fe}(\mathrm{II})$ using the ferrozine assay (Stookey, 1970). Acid extractable Fe(II) concentrations were determined using a standard curve generated from ferrous ammonium sulfate or ferrous ethylene diammonium sulfate. Phosphate was quantified from $0.2 \mu \mathrm{m}$ filtered, $2 \%$ $\mathrm{HNO}_{3}$ acidified samples using a PerkinElmer Optima 2100DC, ICP-OES (PerkinElmer, Waltham, MA, USA).

\section{Reductase activity of recombinant MtrC and OmcA}

Recombinant MtrC and OmcA were isolated as previously described (Shi et al., 2006; Wigginton et al., 2007). The oxidation rates of chemically reduced MtrC and OmcA in the presence of $\mathrm{FH}$ were determined by transient kinetic measurements with absorbance changes at $552 \mathrm{~nm}$ similar to the protocol of Shi et al. (2006) and Xiong et al. (2006) used for measurements of the reduction kinetics for hematite by purified OmcA. The reduction reactions were performed in an anaerobic chamber where the oxygen level was approximately $1 \mathrm{ppm}$. The final concentrations were $5 \mu \mathrm{M}$ of both purified MtrC and OmcA and $150 \mu \mathrm{M}$ for $\mathrm{FH}, \mathrm{Mn}$ (III)pyrophosphate and $\mathrm{MnO}_{2}$. 


\section{RESULTS}

\section{Fe precipitates and cytochromes co-localize on the cell surface of $S$. oneidensis MR-1}

After a 3-day incubation with S. oneidensis MR-1 (Fig. 1A), $\mathrm{FH}$ and a morphologically distinct mineral phase of 10 - to 50nm-wide needle-like crystallites were visible by TEM. Approximately, half of the $5 \mathrm{~mm}$ FH had been reduced by wild-type cells and $<10 \%$ was aqueous $\mathrm{Fe}(\mathrm{II})$ (Table 1 ). Both mineral phases were abundant and often in association with cells. The majority of cells did not appear to accumulate iron on the outer membrane, however, few of the imaged cells displayed globular Fe solids (e.g., 50-100 nm) distributed in a patchy manner at the cell exterior (Fig. 1B). Under these same conditions, antibody specific to the outer-membrane $c$-type cytochrome MtrC labeled the cell exterior and also co-localized with the cell-associated iron precipitates (Fig. 1C) although not all of the cells were labeled. Thin sections of unfixed cells confirmed the co-localization and placed the cytochromes at the cell-Fe solid interface, the cell surface, and the cytoplasm (Fig. 1E). The cytoplasmic localization of MtrC is not surprising as the apoprotein is synthesized in the cytoplasm, secreted to the periplasm via the Sec system where it undergoes maturation and subsequent translocation to the outer membrane via the type II secretion system (Donald et al., 2008; Shi et al., 2008). Although OmcA displayed more diffuse cell surface localization pattern than MtrC (Fig. 1D), similar to MtrC, not all of the cells were labeled. OmcA co-localized with $\mathrm{FH}$ at the cell-Fe solid interface, but qualitatively not to the extent as MtrC (Fig. 1E,F). Thin sections revealed that OmcA was also located outside of the cell in an EPS as evident by the labeling of the sugar-specific lectin, ConA (Fig. IF). The localization of OmcA in the cytoplasm was inconclusive due to significant background in $\Delta m t r C-\Delta o m c A$.

The localization of these cytochromes was also evaluated by immunofluorescence microscopy of cells grown aerobically on basal medium agar plates containing $10 \mathrm{~mm}$
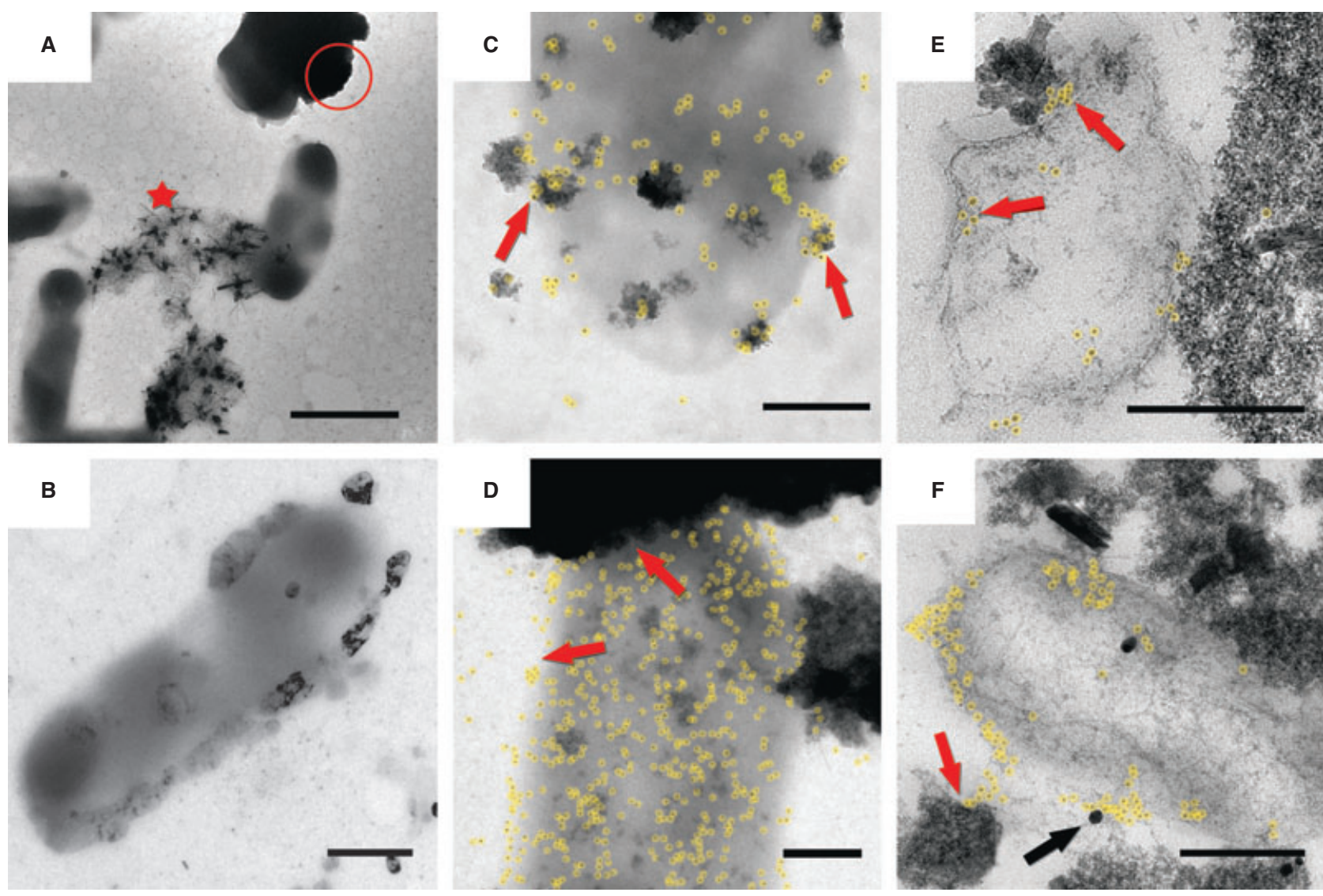

Fig. 1 Photomicrographs of anaerobic, 3-day incubations of Shewanella oneidensis MR-1 with FH. (A) The formation of secondary mineral phases was evident in whole mount samples (indicated by the star) and distinct from the amorphous phase, indicated by the circle. (B) In some cases, iron appeared to accumulate on the cell surface. (C) Immunogold labeling localized MtrC to the outer membrane and in close association with electron dense iron precipitates on the cell surface, while (D) OmcA was distributed more diffusely on the cell exterior. Lowicryl-embedded cryo-sections co-localized (E) MtrC on the outer membrane in association with the iron precipitates and (F) OmcA at the cell exterior in the EPS. (F) Polysaccharides were labeled with $30 \mathrm{~nm}$ gold-conjugated concanavalin A and are indicated by the black arrow. Red arrows point to the areas of immuno-labeling. For enhanced visualization, the antibody-conjugated nano-gold particles are color overlaid. As a comparison, a non-pseudocolored version of this image is provided in Fig. S1. The scale bar denotes $2 \mu \mathrm{m}$ for image A and $0.5 \mu \mathrm{m}$ for all other images. 
Table $1 \mathrm{Fe}(\mathrm{II})$ and $\mathrm{P}$ concentrations from $5 \mathrm{~mm} \mathrm{FH}$ incubations at 3 days

\begin{tabular}{|c|c|c|c|}
\hline \multirow[b]{2}{*}{ Incubation } & \multicolumn{3}{|c|}{ Concentration ( $\mathrm{mM} \pm$ standard deviation) } \\
\hline & Total Fe(II)* & Aqueous Fe(II)* & Aqueous $\mathrm{P}^{\dagger}$ \\
\hline Wild-type & $2.25 \pm 0.17$ & $0.19 \pm 0.00$ & $1.89 \pm 0.04$ \\
\hline$\Delta m t r C-\Delta o m c A$ & $0.43 \pm 0.02$ & $0.08 \pm 0.00$ & $1.90 \pm 0.03$ \\
\hline No inoculum control & $0.28 \pm 0.06$ & $0.03 \pm 0.03$ & $1.17 \pm 0.01$ \\
\hline
\end{tabular}

*Sample was extracted in $0.5 \mathrm{~N} \mathrm{HCl}$, quantified using the ferrozine method. Samples for aqueous $\mathrm{Fe}(\mathrm{II})$ was filtered prior to acidification.

†Sample was filtered, acidified in $2 \% \mathrm{HNO}_{3}$, and quantified by ICP-OES.

$\mathrm{Fe}(\mathrm{III})$-citrate. Similar to FH-incubated cells, only a fraction (c. $25 \%$ ) of the population was labeled with antibody specific to MtrC or OmcA (Fig. 2A,B). Distribution of the cytochromes on the outer membrane was comparable to FH-incubated cells where OmcA (Fig. 2B) was more evenly distributed along the cell exterior with intense clusters of label and MtrC exhibited more restrictive labeling (Fig. 2A). High-resolution TEM revealed cell-to-cell heterogeneities in the density of an unknown iron phase accumulated at the cell surface. Some cells were almost entirely encrusted with iron precipitates while others appeared virtually free of surface precipitates. MtrC was associated with some $\mathrm{Fe}$ precipitates but not abundant on the outer membrane of heavily encrusted cells (Fig. 2C,D). Small (10-20 nm), dense iron aggregates were visualized in proximity to larger iron precipitates and distinguishable from nanogold by size and irregular shape (Fig. 2D, arrow). In an effort to expose MtrC epitopes, oxalic acid was used to dissolve the iron precipitates and, although dissolution was incomplete, the cell surface and remaining iron precipitates were densely labeled with antibody specific for MtrC (Fig. 2E). Based on the darkening of $\mathrm{Fe}(\mathrm{III})$-citrate at the regions of dense growth (Fig. 2F), it is presumable that cellular respiration promoted conditions at the cell-agar interface favorable to $\mathrm{Fe}(\mathrm{III})$ reduction. In this case, the darkening is a direct result of remineralization of the ferrous iron.

\section{Outer-membrane cytochromes are essential for reductive FH biomineralization}

Biotransformation products from $\mathrm{FH}$ reduction were detectable after a 3-day incubation even though both wild-type and
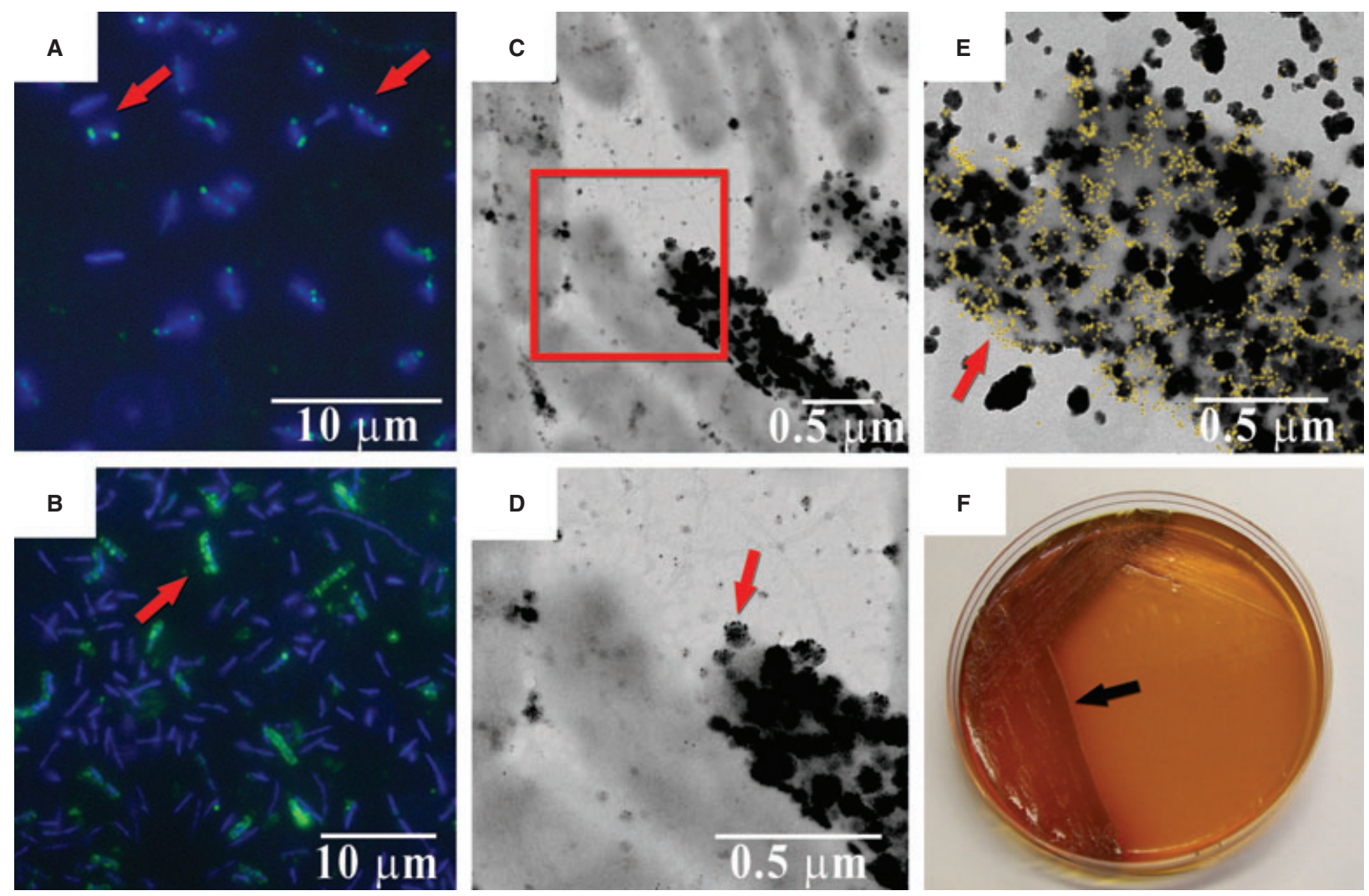

Fig. 2 Photomicrographs of Shewanella oneidensis MR-1 wild-type cells cultured aerobically on Fe(III)-citrate plates. Epifluorescence micrographs of DAPI-stained wild-type cells (blue) demonstrate specific labeling of the cell surface with antibodies against (A) MtrC or (B) OmcA (green). (C) Transmission electron micrographs show heterogeneous populations of cells with varying degrees of precipitation of electron dense material, presumably iron, on the cell surfaces. (D) A magnified view of the highlighted area in image C illustrates that the cell surfaces were sparsely if at all labeled with MtrC-specific antibody. Small dense precipitates (indicated by red arrow) of similar size to nanogold but irregular shape were associated with the larger Fe solids on cell surface. (E) After partial dissolution of the surface iron by oxalic acid, MtrC was readily detected on the cell surface. Red arrows point to the areas of immuno-labeling. (F) Darkened zones on the Fe-citrate plates were visible after aerobic incubation of MR-1. For comparison, non-pseudocolored version of this image is provided in Fig. S2. 
$\Delta m \operatorname{tr} C-\Delta o m c A$ cells were able to colonize and aggregate $\mathrm{FH}$ particles (data not shown). Morphologically distinct mineral phases were observed by TEM in the wild-type cell suspensions including needle-like crystallites and a platey phase of variable width as well as amorphous aggregates similar in appearance to unreduced $\mathrm{FH}$ and/or $\mathrm{FH}$ aggregates (Fig. 3A). These solids did not readily adhere to the EM grids and were only detected in whole mount preparations of concentrated sample. The platey phase had cell-sized and shaped holes or gaps often located near the mineral edge (Fig. 3B) and some of cells appear to be encased in the mineral (Fig. 3C).

Scanning electron microscopic analysis of dehydrated sample revealed two different mineral morphologies, one of which (center) appeared to be formed by multiple platey phases (Fig. 3D). EDS analysis of the minerals imaged by SEM confirmed that both were composed of iron and phosphate (data not shown). Cells were not abundant on the mineral surfaces of the dehydrated samples so, in an effort to capture the native microbe-mineral associations, hydrated samples were analyzed by cryo-SEM. Two florets with maximum diameters of approximately $75 \mu \mathrm{m}$ demonstrated a close association of the cells with the mineral surface (Fig. 3E,F). Confocal and epifluorescence microscopy confirmed the results of the cryo-SEM revealing dense populations of cells associated with the mineral surfaces (Fig. 3G). MtrC immunofluorescence microscopy detected the exposed cytochrome at surfaces of cells associated with the secondary mineral phase indicating that the cytochromes remained cell surface-exposed even after biotransformation of $\mathrm{FH}$ (Fig. $3 \mathrm{H}$ ).

The large size and distinguishable morphology of the platey phase made it possible to analyze a single crystal aggregate using micro-XRD. Two different colored phases, a pale and deeper brown, were evident on the aggregate and both were positively identified as vivianite $\mathrm{Fe}^{2+}{ }_{3}\left(\mathrm{PO}_{4}\right)_{2} \cdot 8 \mathrm{H}_{2} \mathrm{O}$ (Fig. 4). The unmatched peak at $458^{\circ} \theta$ could not be attributed to any known phase and may be a result of moderate randomization of the vivianite crystal not observed in the reference diffraction patterns from powder samples. Bulk samples were analyzed by micro-XRD as hydrated slurries to identify the other mineral phases imaged by TEM. Vivianite and switzerite $\left[\left(\mathrm{Mn}^{2+}\right.\right.$, $\left.\left.\mathrm{Fe}^{2+}\right)_{3}\left(\mathrm{PO}_{4}\right)_{2} \cdot 7 \mathrm{H}_{2} \mathrm{O}\right]$ were the only identifiable phases (Fig. 5). Centrifugation of the capillaries resulted in visible stratification of the minerals. Micro-XRD analysis of the different layers confirmed the partitioning of the phases with enrichment of vivianite at the bottom of the capillary and amorphous iron at the top as shown by the broad hump centered at $40^{\circ} \theta$ (Fig. 5). In the absence of the two OMCs, MtrC and OmcA, no crystalline mineral phases were detected by micro-XRD analysis in 11-day incubations (Fig. S3 in the
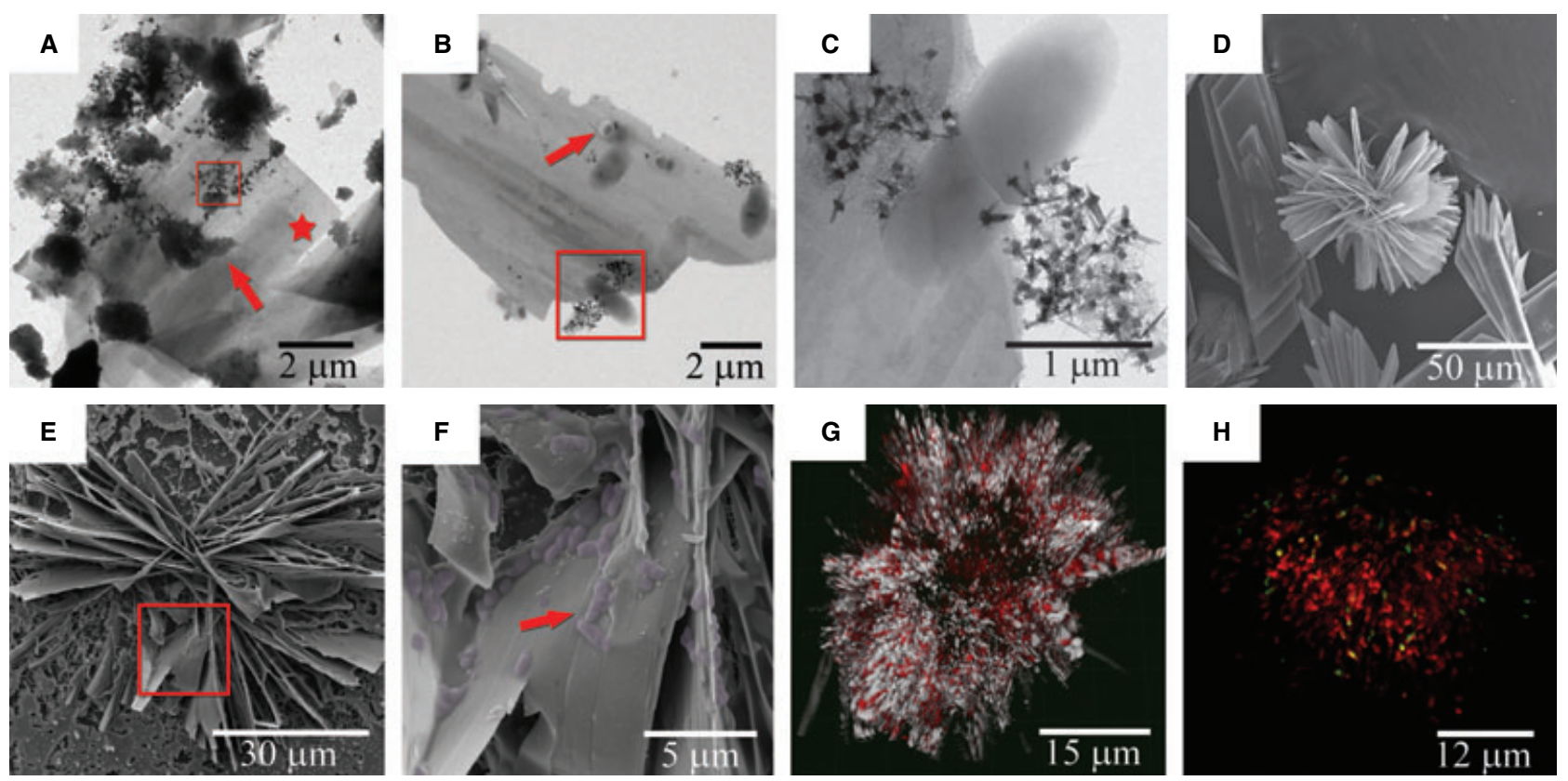

Fig. 3 Micrographs of the secondary mineral phases formed during incubation of Shewanella oneidensis MR-1 wild-type cells with FH. (A) After 3 days, different mineral phases distinguishable from $\mathrm{FH}$ (red arrow) are indicated by a square (needle-like) and star (plate-like). (B) Images of a suspension subsample after incubation for 11 days reveal the presence of the two morphologically distinct phases (platey and needle-like) in close association with cells. (C) Magnified area showing a cell partially engulfed in the platey mineral phase that is composed primarily of Fe and P as determined by EDS. (D) Two morphologically distinct phases of Fe-P minerals are evident in dehydrated samples imaged by scanning electron microscopy including 50-100 $\mu \mathrm{m}$ diameter florets (center) and the larger plate-shaped phase noted above. (E,F) Cryo-SEM image of a hydrated floret illustrating the close association of cells with the mineral surface. (G) A mineral floret densely populated by cells stained by Syto59 (red) when imaged by confocal microscopy under hydrated conditions (iron mineral was imaged using reflection and appears gray). (H) Immunolocalization of MtrC on the surface of the cells colonizing the secondary mineral phase. 
Fig. 4 Diffractogram of the secondary mineral phase formed by wild-type cells incubated 11 days with $5 \mathrm{~mm}$ FH. Micro-XRD analysis of an aggregate of the platey phase identified the mineral as vivianite. The approximate regions of analysis are circled.

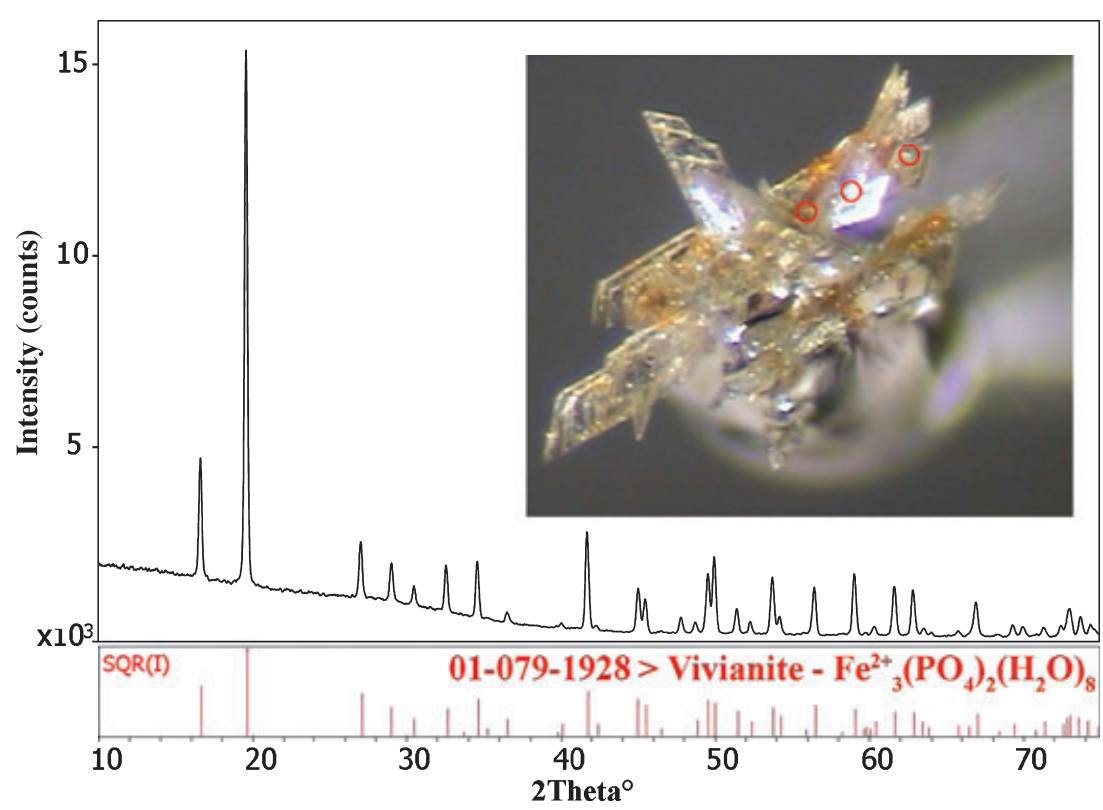

Supporting Information). Visible stratification of mineral phases was not evident upon centrifugation of the bulk sample and the diffractogram differed little from the no inoculum control.

\section{The presence of either MtrC or OmcA is critical for reductive FH biomineralization}

The lack of $\mathrm{FH}$ transformation products by $\Delta m+r C-\Delta o m c A$ was confirmed by the inability of the mutant to reduce $\mathrm{FH}$ (Fig. 6A). Deletion of only one OMC, however, had little effect on iron reduction rates; compared to the wild-type, which reduced $\mathrm{FH}$ at a rate of $31 \mu \mathrm{M} \mathrm{h} \mathrm{h}^{-1}$ (i.e., $5 \times 10^{4}$ electrons cell $\left.{ }^{-1} \mathrm{~s}^{-1}\right)$ the average rate for $\Delta m t r C$ was $28 \mu \mathrm{M} \mathrm{h}^{-1}$ (i.e., $4.5 \times 10^{4}$ electron cell $^{-1} \mathrm{~s}^{-1}$ ) and $\Delta o m c A$ was $27 \mu \mathrm{M} \mathrm{h}^{-1}$ (i.e., $4.3 \times 10^{4}$ electrons cell ${ }^{-1} \mathrm{~s}^{-1}$ ). Interestingly, $\Delta m t r C-\Delta o m c A$ was not compromised in the ability to reduce soluble iron complexed by citrate (Fig. 6B) or NTA (Fig. 6C) indicating that these OMCs are not essential for efficient reduction of soluble forms of $\mathrm{Fe}$ (III) although both proteins can transfer electrons to these complexed forms of $\mathrm{Fe}(\mathrm{III})$ in vitro (Wang et al., 2008). Complementation of $\Delta m t r C-$ $\Delta o m c A$ fully restored $\mathrm{FH}$ reduction to wild-type levels (data not shown).
Fig. 5 Stacked diffractograms from the analysis of the hydrated bulk phase. The sample was stratified by centrifugation and analyses were taken at each of the visibly different phases. Vivianite and switzerite are the two predominant mineral phases after an 11-day incubation.

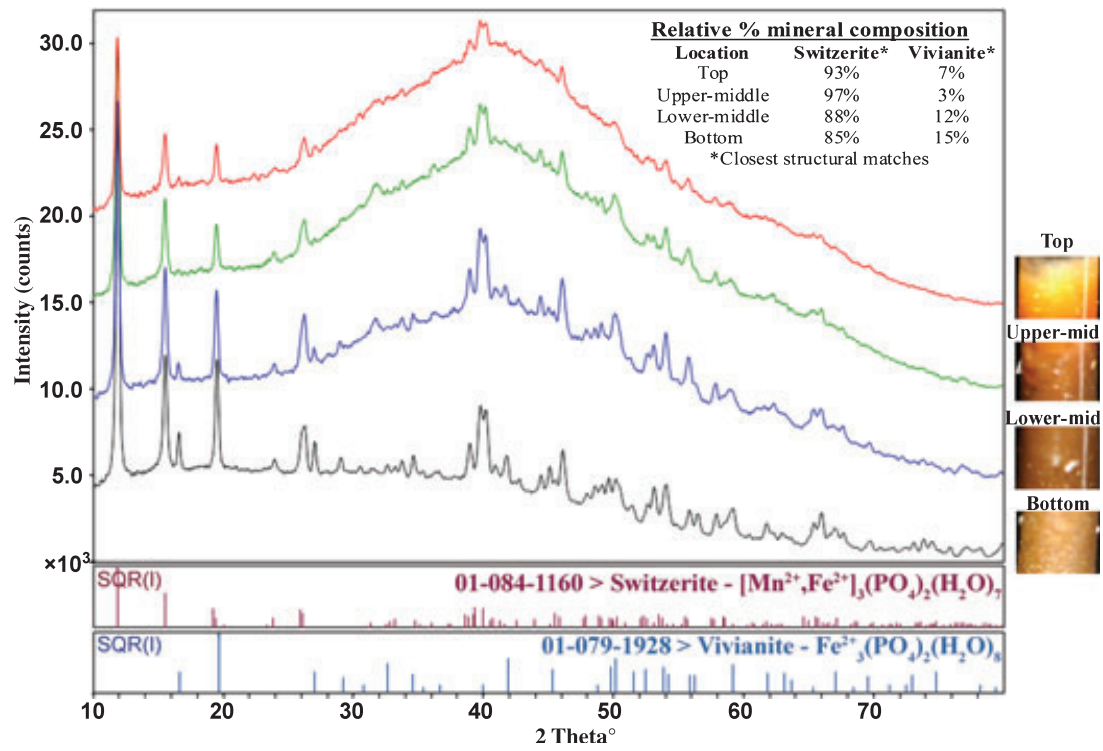



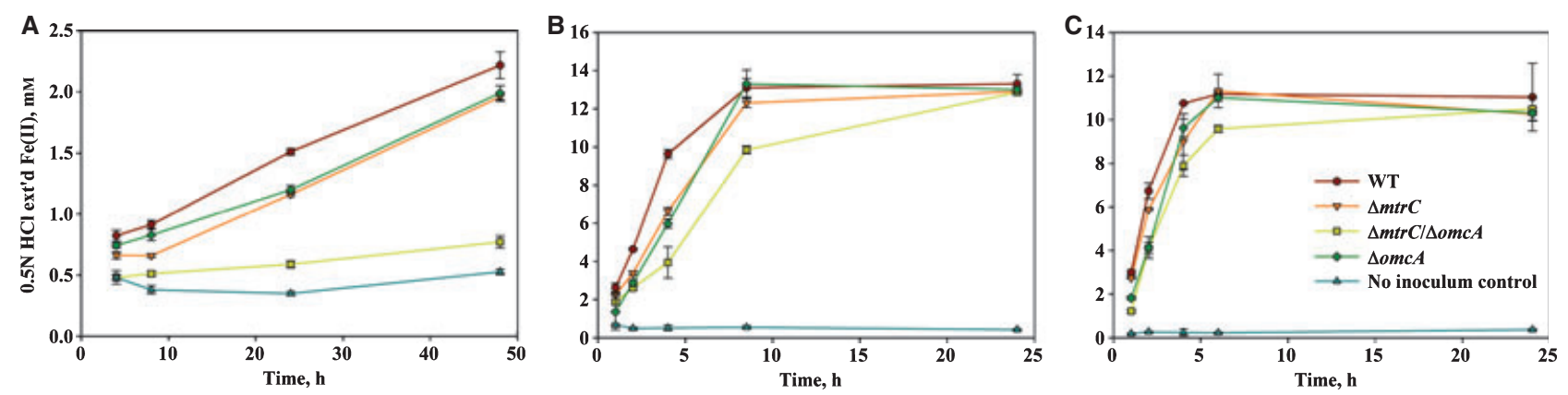

Fig. 6 Reduction of soluble and insoluble iron by wild-type, $\Delta m \operatorname{trC}, \Delta o m c A$, and $\Delta m \operatorname{trC}-\Delta o m c A$ strains. Kinetics are shown for (A) $10 \mathrm{~mm} \mathrm{FH}$, (B) $10 \mathrm{~mm}$ Fe(III)citrate, and (C) $10 \mathrm{~mm}$ Fe(III)-NTA. The data points and error bars represent the mean values and standard deviations of triplicate cultures, respectively.

The FH reductase activities of MtrC and OmcA were also measured in vitro using purified, recombinant proteins. Chemically-reduced MtrC and OmcA were oxidized rapidly when added to $\mathrm{FH}$. The electron transfer rates of MtrC to FH $\left(0.025 \pm 0.004\right.$ electrons $\left.s^{-1}, n=3\right)$ exceeded those measured for OmcA $\left(0.011 \pm 0.003\right.$ electrons s $\left.{ }^{-1}\right)$, which is consistent with previous observations for soluble and insoluble forms of complexed $\mathrm{Fe}$ (III) and radionuclides (Marshall et al., 2006, 2008; Shi et al., 2006; Xiong et al., 2006; Wang et al., 2008; Meitl et al., 2009). Electron transfer to $\mathrm{MnO}_{2}$ had similar rates of $0.011 \pm 0.007$ and $0.007 \pm 0.001$ electrons $\mathrm{s}^{-1}$ for MtrC and OmcA, respectively. Differences between the MtrC and OmcA in vitro electron transfer rates were consistent regardless of the electron acceptor and may reflect differences in the electrochemical properties of these two OMCs (Wigginton et al., 2007; Firer-Sherwood et al., 2008).

\section{DISCUSSION}

Direct electron transfer to metal oxides by OMCs is dependent not only on their electrochemical properties but also on their physical proximity relative to the mineral surface. The distance for effective electron transfer between the OMC and the Fe oxide surface is probably limited to $10 \AA$ or less (Kerisit et al., 2007), therefore the OMCs must be essentially in direct contact for transfer to occur in the absence of a mediator or shuttle. Cell surface exposure of MtrC and OmcA is well documented and has been previously shown with cells respiring $\mathrm{O}_{2}$ (Shi et al., 2008), fumarate (Myers \& Myers, 1992, 2003a), U(VI) (Marshall et al., 2006) and hematite (Lower et al., 2009). In this study, cells incubated with soluble and insoluble forms of $\mathrm{Fe}$ (III) had similar cytochrome localization patterns. Iron solids also accumulated on the cell surface and co-localized with these cytochromes. This is not surprising as bacterial membranes readily sorb soluble and nano-grained metals including iron (hydr)oxides (Beveridge, 1989; Glasauer et al., 2001). In the case of soluble metals, the degree of sorption can be significant enough to form mineral precipi- tates at the cell surface that are visible by electron microscopy (Beveridge, 1989). In our study, the exact reasons for the heterogeneity in the degree of iron accumulation on the cell surfaces are unclear but may be due to inaccessibility of the cytochromes resulting from EPS 'shielding' (Lower et al., 2007) or perhaps incomplete mixing stemming from $\mathrm{FH}$ and/or cell aggregation. It is difficult to conclude the etiology of the mineral precipitates and whether the deposition occurred actively (reduction at the outer membrane or EPS) or passively (sorption). The placement of the cytochromes, especially MtrC, at the cell-sorbed Fe oxide interface suggests the former.

The immunolocalization of MtrC and OmcA displayed by $\mathrm{Fe}(\mathrm{III})$-reducing cells of $S$. oneidensis MR-1 was complicated by the heavy accumulation of iron precipitates on the cell surface and the cell-to-cell heterogeneity in label intensity. Nonetheless, similar localization patterns were observed in cells incubated anaerobically with $\mathrm{FH}$ or cultivated aerobically on $\mathrm{Fe}$ (III)-citrate agar plates suggesting that the labeling may reflect the physiological state of the cell, among other factors. In the case of the Fe-citrate plates, the cells at the air interface likely had decreased levels of OMCs as the expression of the $m \operatorname{tr} C A B-o m c A$ locus is suppressed under fully aerobic conditions (Charania et al., 2009). The cytochrome content of the outer membrane significantly increases upon the onset of anaerobic conditions (Myers \& Myers, 1992) and it is possible that cells displaying high density of labeling originated deeper in the colony where $\mathrm{O}_{2}$ is depleted. Although the presence of an $\mathrm{O}_{2}$ gradient may potentially affect the distribution of MtrC and OmcA on the surface of $S$. oneidensis MR-1 cells grown on Fe-citrate plates, it does not address the heterogeneity issue observed in anaerobic cell suspensions incubated with $\mathrm{FH}$. Alternately, the heterogeneous labeling patterns could result from epitope blocking or varying extracellular exposure of the individual cytochromes. The intensity of MtrC labeling on the surface of Fe-citrate incubated cells was significantly increased by pretreatment with oxalic acid, an effective Fe(III) complexing ligand (Suter et al., 1988). Additionally, the oxalic acid treatment may have exposed the MtrC 
epitopes by complexing $\mathrm{Ca}^{2+}$, which is involved in maintaining EPS integrity in MR-1 (McLean et al., 2008).

While purified MtrC and OmcA exhibit some differences in regard to their biochemical and biophysical properties (Lower et al., 2007; Wigginton et al., 2007; Firer-Sherwood et al., 2008; Marshall et al., 2008; Wang et al., 2008), they both are facile electron transfer proteins that can form a complex both in vitro and in vivo (Shi et al., 2006). MtrC transfers electrons more rapidly than OmcA to several metal substrates including $\mathrm{Mn}$ and $\mathrm{Fe}(\mathrm{III})$ oxides (this study), $\mathrm{Fe}(\mathrm{III})-\mathrm{NTA}, \mathrm{Fe}(\mathrm{III})$ citrate, $\mathrm{Fe}(\mathrm{III})$-EDTA (Wang et al., 2008) and $\mathrm{TcO}_{4}{ }^{-}$ (Marshall et al., 2008). Unlike MtrC, OmcA does not exhibit any measurable electron transfer to uranyl citrate (Marshall et al., 2006, 2008). The difference in the electrochemical properties of the two cytochromes is likely an intrinsic effect of structural differences as electron transfer rate is strongly dependent on heme porphyrin ring orientation and distance of electron transfer (Kerisit et al., 2007) in addition to substrate solubility and nature of the complexing ligand (Wang et al., 2008). In addition, a recent study (Meitl et al., 2009) suggests that purified OmcA may behave differently in vitro compared to in vivo when it is expressed on the cell surface. Notably, purified MtrC and the $\Delta o m c A$ mutant behaved almost identically in terms of mediating electron transfer to a hematite electrode surface, while purified OmcA transferred electrons less effectively to the hematite electrode than the $\Delta m t r C$ mutant (Meitl et al., 2009).

The ability of $S$. onedensis MR-1 cells to reduce solid-phase metals in the absence of one but not both cytochromes, further supports the concept that these are functionally redundant proteins. However, the reduction of $\mathrm{Fe}(\mathrm{III})$-citrate and $\mathrm{Fe}$ (III)-NTA by $\Delta m t r C-\Delta o m c A$ implies that neither MtrC or OmcA are essential for soluble metal reduction. These results are in contrast with an earlier study (Borloo et al., 2007), which suggested that these proteins are required for the reduction of chelated soluble $\mathrm{Fe}$ (III) as an insertional inactivation of MtrC abolished the reduction $\mathrm{Fe}$ (III) citrate and $\mathrm{Fe}(\mathrm{III}) \mathrm{NTA}$. The discrepancy is likely to stem from the approach used by Borloo et al. (2007), in which suicide vector integration was employed to generate gene knockouts in a spontaneous rifampicin resistant strain of $S$. oneidensis MR-1. Insertional mutagenesis of $m \operatorname{tr} C$ is complicated by the chromosomal organization of metal reduction genes in $S$. oneidensis MR-1, where $m t r C$ is co-expressed as part of the $m+r C A B$ operon (Beliaev et al., 2001). As shown previously, a transposon insertion in $m t r C$ abolishes the expression of downstream $m \operatorname{tr} A B$ and dramatically decreases the reduction rates of both soluble and insoluble Fe(III) by $S$. oneidensis MR-1 (Beliaev et al., 2001). Recent studies have confirmed the criticality of the $m \operatorname{tr} A B$ complex in metal reduction showing that the resulting products form a novel trans-membrane complex required for the electron exchange with the metal electron acceptors (Hartshorne et al., 2009). Therefore, to avoid potential polar effects and cleanly assess the phenotypes of
S. oneidensis MR-1 strains lacking MtrC and/or OmcA, we made deletion mutagenesis a method of choice for our study.

Although the presented data on the in vivo and in vitro kinetics of $\mathrm{FH}$ reduction by $S$. oneidensis MR-1 support the direct electron transfer mechanism, one needs to exercise caution when extrapolating these finding to other experimental conditions and systems. Recent findings of Ross et al. (2009) demonstrated slow reduction rates of goethite by purified MtrC and OmcA in the absence of riboflavin, indicating that the OMCs of $S$. oneidensis MR-1 do not function as in vivo terminal reductases during the transfer electron to goethite. They also concluded that $\mathrm{MtrC}$ and OmcA require flavins as electron shuttles to transfer electrons to goethite indirectly. In contrast, Meitl et al. (2009) reported that both MtrC and OmcA can directly transfer electrons to a hematite. This observation was based on the results of comparative analysis of the in vitro and in vivo electrochemical properties of MtrC and OmcA on the hematite electrode surface. In a separate study, Baron et al. (2009) found that S. oneidensis MR-1 cells used two pathways to transfer electrons to the surface of a carbon electrode, in which MtrC and OmcA were the terminal reductases of a direct pathway while the secreted flavins were the critical part of an indirect pathway.

Mechanistic knowledge of the electron transfer pathways is important for understanding factors affecting the biogeochemical cycling of metals. The nature of the biomineralization products is strongly influenced by the availability of $\mathrm{P}$ and, in the presence of $\mathrm{P}$, vivianite $\left[\mathrm{Fe}_{3}^{2+}\left(\mathrm{PO}_{4}\right)_{2} \cdot 8 \mathrm{H}_{2} \mathrm{O}\right]$ is a common product of microbial iron reduction (Fredrickson et al., 1998; Zachara et al., 2001, 2002; Kukkadapu et al., 2004; Borch et al., 2007; Yan et al., 2008). Under the experimental conditions reported herein, switzerite $\left[\mathrm{Mn}^{2+}, \mathrm{Fe}_{3}^{2+}\left(\mathrm{PO}_{4}\right)_{2} \cdot 7 \mathrm{H}_{2} \mathrm{O}\right]$ (Leavens \& White, 1967; White et al., 1986) or a switzerite-like phase was the predominant iron phosphate mineral formed during incubation with wild-type cells. Switzerite and vivianite are monoclinic crystals and vary in chemical composition by one hydration point and potential $\mathrm{Mn}^{2+}$ substitution. The presence of the two phases does not appear to be an artifact of drying since the bulk analyses were conducted under fully hydrated conditions. Furthermore, based on the microscopic analysis and $\mathrm{XRD}$, these two ferrous phosphate phases appear to have very distinct morphologies and crystal structures. This is the first report of a switzerite-like phase produced under microbial $\mathrm{Fe}(\mathrm{III})$-reducing conditions and its genesis remains unknown. It also remains unclear whether the composition and/or morphology of the $\mathrm{FH}$ biomineralization products results from a direct biotically driven reaction (i.e., reduced at the outer membrane and precipitated by nucleation by the OMCs or EPS) or an indirect abiotically driven reaction via the microbially induced reduction and chemical precipitation of $\mathrm{Fe}(\mathrm{II})$ and $\mathrm{PO}_{4}$ ions from solution. In both each cases, the initial $\mathrm{FH}$ reduction could be mediated by the 
OMCs and/or endogenous electron shuttles such as flavins (von Canstein et al., 2008; Marsili et al., 2008) or melanin (Turick et al., 2009). In our study, however, the intimate association of cells with the iron phosphate minerals, either on the surface or entrained within the structure, suggests a direct biological interaction.

Phosphate has a strong affinity toward FH and sorbs to the mineral surface (Fredrickson et al., 1998; Kukkadapu et al., 2004), which was evident in the mutant and abiotic controls where the aqueous phosphate concentration was reduced to nearly half of the starting concentration. Phosphate has been shown to increase the extent of $\mathrm{Fe}(\mathrm{III})$ reduction by Shewanella putrefaciens CN32 (Kukkadapu et al., 2004), but even in the presence of aqueous phosphate at 11 days, no secondary mineral phases were detected in incubations with $\Delta m t r C-\Delta o m c A$ cells, supporting the case that these proteins are essential for the reductive biomineralization of $\mathrm{FH}$. The in vivo kinetics confirmed previous studies demonstrating significant deficiencies in solid-phase iron reduction upon deletion of the OMCs, MtrC, and OmcA (Gorby et al., 2006; Bretschger et al., 2007). Although the collective results from this study do not exclude the involvement of other electron transfer mechanisms such as soluble electron shuttles, they do suggest that they are either insignificant under the experimental conditions or require interaction with the OMCs. The results of this study support a role for cytochrome-mediated electron transfer by co-localizing the cytochromes to the outer membrane and in association with $\mathrm{FH}$ aggregates at the cell surface. The importance of the outer-membrane cytochromes in iron oxide reduction is evident and reflected by the inability of cells lacking both cytochromes to biotransform FH. Further studies, however, are required to elucidate the mechanisms of biomineralization and the extent to which the bacteria play a role in the formation of the observed phases other than via $\mathrm{Fe}(\mathrm{II})$ generation.

\section{ACKNOWLEDGEMENTS}

We thank Dr Heather Owen and Sheetal Shirodkar for assistance with the electron microscopy imaging, Anthony Addlagatta for help with the micro-XRD analysis, and Dr Margaret Romine, Samantha Bree Reed, David E. Culley and Yang Zhang for mutant construction and complementation analysis. This research was supported by the U.S. Department of Energy (DOE) Office of Biological and Environmental Research under the Genomics:GTL Program via the Shewanella Federation consortium, by the Pacific Northwest National Laboratory (PNNL) Biogeochemistry Grand Challenge and by EMSL Scientific Grand Challenge project at the W. R. Wiley Environmental Molecular Sciences Laboratory, a national scientific user facility sponsored by OBER and located at PNNL. Pacific Northwest National Laboratory is operated for the DOE by Battelle Memorial Institute under Contract DE-AC05-76RLO 1830.

\section{REFERENCES}

Baron DB, LaBelle E, Coursolle D, Gralnick JA, Bond DR (2009) Electrochemical measurement of electron transfer kinetics by Shewanella oneidensis MR-1. Journal of Biological Chemistry 284, 28865-28873.

Beliaev AS, Saffarini DA (1998) Shewanella putrefaciens $m$ trB encodes an outer membrane protein required for $\mathrm{Fe}(\mathrm{III})$ and $\mathrm{Mn}(\mathrm{IV})$ reduction. Journal of Bacteriology 180, 6292-6297.

Beliaev AS, Saffarini DA, McLaughlin JL, Hunnicutt D (2001) MtrC, an outer membrane decahaem $c$ cytochrome required for metal reduction in Shewanella putrefaciens MR-1. Molecular Microbiology $39,722-730$.

Beveridge TJ (1989) Role of cellular design in bacterial metal accumulation and mineralization. Anmual Review of Microbiology 43, 147-171.

Borch T, Masue Y, Kukkadapu RK, Fendorf S (2007) Phosphate imposed limitations on biological reduction and alteration of ferrihydrite. Environmental Science \& Technology 41, 166-172.

Borloo J, Vergauwen B, De Smet L, Brige A, Motte B, Devreese B, Van Beeumen J (2007) A kinetic approach to the dependence of dissimilatory metal reduction by Shewanella oneidensis MR-1 on the outer membrane cytochromes c OmcA and OmcB. FEBS Journal 274, 3728-3738.

Braun TF, McBride MJ (2005) Flavobacterium johnsoniae GldJ is a lipoprotein that is required for gliding motility. Journal of Bacteriology 187, 2628-2637.

Bretschger O, Obraztsova A, Sturm CA, Chang IS, Gorby YA, Reed SB, Culley DE, Reardon CL, Barua S, Romine MF, Zhou J, Beliaev AS, Bouhenni R, Saffarini D, Mansfeld F, Kim B-H, Fredrickson JK, Nealson KH (2007) Current production and metal oxide reduction by Shewanella oneidensis MR-1 wild type and mutants. Applied and Environmental Microbiology 73, 7003-7012.

von Canstein H, Ogawa J, Shimizu S, Lloyd JR (2008) Secretion of flavins by Shewanella species and their role in extracellular electron transfer. Applied and Environmental Microbiology 74, 615-623.

Charania MA, Brockman KL, Zhang Y, Banerjee A, Pinchuk GW, Fredrickson JK, Beliaev AS, Saffarini DA (2009) Involvement of a membrane-bound class III adenylate cyclase in regulation of anaerobic respiration in Shewanella oneidensis MR-1. Journal of Bacteriology 191, 4298-4306.

Cornell RM, Schwertmann U (1996) The Iron Oxides. VCH Publishers, New York.

Donald JW, Hicks MG, Richardson DJ, Palmer T (2008) The $c$-type cytochrome OmcA localizes to the outer membrane upon heterologous expression in Escherichia coli. Journal of Bacteriology 190, 5127-5131.

El-Naggar MY, Gorby YA, Xia W, Nealson KH (2008) The molecular density of states in bacterial nanowires. Biophysical Journal 95, L10-L12.

Firer-Sherwood M, Pulcu GS, Elliott SJ (2008) Electrochemical interrogations of the Mtr cytochromes from Shewanella: opening a potential window. Journal of Biological Inorganic Chemistry 13, 849-854.

Fredrickson JK, Zachara JM (2008) Electron transfer at the microbemineral interface: a grand challenge in biogeochemistry. Geobiology $6,245-253$.

Fredrickson JK, Zachara JM, Kennedy DW, Dong H, Onstott TC, Hinman NW, Li SW (1998) Biogenic iron mineralization accompanying the dissimilatory reduction of hydrous ferric oxide by a groundwater bacterium. Geochimica et Cosmochimica Acta 62, 3239-3257.

Glasauer S, Langley S, Beveridge TJ (2001) Sorption of Fe (hydr)oxides to the surface of Shewanella putrefaciens: cell-bound 
fine-grained minerals are not always formed de novo. Applied and Environmental Microbiology 67, 5544-5550.

Gorby YA, Yanina S, McLean JS, Rosso KM, Moyles D, Dohnalkova A, Beveridge TJ, Chang IS, Kim BH, Kim KS, Culley DE, Reed SB, Romine MF, Saffarini DA, Hill EA, Shi L, Elias DA, Kennedy DW, Pinchuk G, Watanabe K, Ishii S, Logan B, Nealson KH, Fredrickson JK (2006) Electrically conductive bacterial nanowires produced by Shewanella oneidensis strain MR-1 and other microorganisms. Proceedings of the National Academy of Sciences of the United States of America 103, 11358-11363.

Gralnick JA, Newman DK (2007) Extracellular respiration. Molecular Microbiology 65, 1-11.

Hansel CM, Benner SG, Neiss J, Dohnalkova A, Kukkadapu RK, Fendorf S (2003) Secondary mineralization pathways induced by dissimilatory iron reduction of ferrihydrite under advective flow. Geochimica et Cosmochimica Acta 67, 2977-2992.

Hansel CM, Benner SG, Nico P, Fendorf S (2004) Structural constraints of ferric (hydr)oxides on dissimilatory iron reduction and the fate of $\mathrm{Fe}(\mathrm{II})$. Geochimica et Cosmochimica Acta 68, 32173229.

Hartshorne RS, Reardon CL, Ross DE, Neuster J, Clarke TA, Gates AJ, Fredrickson JK, Zachara JM, Shi L, Beliaev AS, Marshall MJ, Tien M, Brantley SL, Butt JN, Richardson DJ (2009) Characterization of an electron conduit between bacteria and the extracellular environment. Proceedings of the National Academy of Sciences of the United States of America, doi: 10.1073/pnas.0900086106.

Kerisit S, Rosso KM, Dupuis M, Valiev M (2007) Molecular computational investigation of electron-transfer kinetics across cytochrome-iron oxide interfaces. The Journal of Physical Chemistry. C, Nanomaterials and Interfaces 111, 11363-11375.

Kukkadapu RK, Zachara JM, Fredrickson JK, Kennedy DW (2004) Biotransformation of two-line silica-ferrihydrite by a dissimilatory $\mathrm{Fe}(\mathrm{III})$-reducing bacterium: formation of carbonate green rust in the presence of phosphate. Geochimica et Cosmochimica Acta 68, 2799-2814.

Leang C, Coppi MV, Lovley DR (2003) OmcB, a c-type polyheme cytochrome, involved in $\mathrm{Fe}$ (III) reduction in Geobacter sulfurreducens. Journal of Bacteriology 185, 2096-2103.

Leavens PB, White JSJ (1967) Switzerite, $(\mathrm{Mn}, \mathrm{Fe})_{3}\left(\mathrm{PO}_{4}\right)_{2} \cdot 4 \mathrm{H}_{2} \mathrm{O}$, A new mineral. The American Mineralogist 52, 1595-1602.

Lovley DR, Greening RC, Ferry JG (1984) Rapidly growing rumen methanogenic organism that synthesizes coenzyme $\mathrm{M}$ and has a high affinity for formate. Applied and Environmental Microbiology 48, 81-87.

Lovley DR, Coates JD, Blunt-Harris EL, Phillips EJP, Woodward JC (1996) Humic substances as electron acceptors for microbial respiration. Nature 382, 445 .

Lower BH, Shi L, Yongsunthon R, Droubay TC, McCready DE, Lower SK (2007) Specific bonds between an iron oxide surface and outer membrane cytochromes MtrC and OmcA from Shewanella oneidensis MR-1. Journal of Bacteriology 189, 4944-4952.

Lower BH, Yongsunthon R, Shi L, Wildling L, Gruber HJ, Wigginton NS, Reardon CL, Pinchuk GE, Droubay TC, Boily JF, Lower SK (2009) Antibody recognition force microscopy shows that outer membrane cytochromes OmcA and MtrC are expressed on the exterior surface of Shewanella oneidensis MR-1. Applied and Environmental Microbiology 75, 2931-2935.

Magnuson TS, Isoyama N, Hodges-Myerson AL, Davidson G, Maroney MJ, Geesey GG, Lovley DR (2001) Isolation, characterization and gene sequence analysis of a membrane-associated $89 \mathrm{kDa} \mathrm{Fe}(\mathrm{III})$ reducing cytochrome $c$ from Geobacter sulfurred $u$ cens. The Biochemical Journal 359, 147-152.
Marshall MJ, Beliaev AS, Dohnalkova AC, Kennedy DW, Shi L, Wang Z, Boyanov MI, Lai B, Kemner KM, McLean JS, Reed SB, Culley DE, Bailey VL, Simonson CJ, Saffarini DA, Romine MF, Zachara JM, Fredrickson JK (2006) $c$-Type cytochrome-dependent formation of U(IV) nanoparticles by Shewanella oneidensis. PLoS Biology 4, e268.

Marshall MJ, Plymale AE, Kennedy DW, Shi L, Wang Z, Reed SB, Dohnalkova AC, Simonson CJ, Liu C, Saffarini DA, Romine MF, Zachara JM, Beliaev AS, Fredrickson JK (2008) Hydrogenase- and outer membrane $c$-type cytochrome-facilitated reduction of technetium(VII) by Shewanella oneidensis MR-1. Environmental Microbiology 10, 125-136.

Marsili E, Baron DB, Shikhare ID, Coursolle D, Gralnick JA, Bond DR (2008) Shewanella secretes flavins that mediate extracellular electron transfer. Proceedings of the National Academy of Sciences of the United States of America 105, 3968-3973.

McLean JS, Pinchuk GE, Geydebrekht OV, Bilskis CL, Zakrajsek BA, Hill EA, Saffarini DA, Romine MF, Gorby YA, Fredrickson JK, Beliaev AS (2008) Oxygen-dependent autoaggregation in Shewanella oneidensis MR-1. Environmental Microbiology 10, 1861-1876.

Mehta T, Coppi MV, Childers SE, Lovley DR (2005) Outer membrane c-type cytochromes required for $\mathrm{Fe}(\mathrm{III})$ and $\mathrm{Mn}(\mathrm{IV})$ oxide reduction in Geobacter sulfurreducens. Applied and Environmental Microbiology 71, 8634-8641.

Meitl LA, Eggleston CM, Colberg PJ, Reardon CL, Shi L (2009) Electrochemical interaction of Shewanella oneidensis MR-1 and its outer membrane cytochromes OmcA and MtrC with hematite electrodes. Geochimica et Cosmochimica Acta 73, 5292-5307.

Myers CR, Myers JM (1992) Localization of cytochromes to the outer membrane of anaerobically grown Shewanella putrefaciens MR-1. Journal of Bacteriology 174, 3429-3438.

Myers JM, Myers CR (1998) Isolation and sequence of $o m c A$, a gene encoding a decaheme outer membrane cytochrome $c$ of Shewanella putrefaciens MR-1, and detection of omc $A$ homologs in other strains of S. putrefaciens. Biochimica et Biophysica Acta 1373, 237-251.

Myers JM, Myers CR (2001) Role for outer membrane cytochromes OmcA and OmcB of Shewanella putrefaciens MR-1 in reduction of manganese dioxide. Applied and Environmental Microbiology 67, 260-269.

Myers CR, Myers JM (2003a) Cell surface exposure of the outer membrane cytochromes of Shewanella oneidensis MR-1. Letters in Applied Microbiology 37, 254-258.

Myers JM, Myers CR (2003b) Overlapping role of the outer membrane cytochromes of Shewanella oneidensis MR-1 in the reduction of manganese(IV) oxide. Letters in Applied Microbiology 37, 21-25.

Myers CR, Myers JM (2004) The outer membrane cytochromes of Shewanella oneidensis MR-1 are lipoproteins. Letters in Applied Microbiology 39, 466-470.

Neal AL, Rosso KM, Geesey GG, Gorby YA, Little BJ (2003) Surface structure effects on direct reduction of iron oxides by Shewanella oneidensis. Geochimica et Cosmochimica Acta 67, 4489-4503.

Newman DK, Kolter R (2000) A role for excreted quinones in extracellular electron transfer. Nature 405, 94-97.

O'Connell SP (2007) Cultivation of bacteria and fungi. In Manual of Environmental Microbiology (eds Hurst CJ, Crawford R, Garland JL, Lipson DA, Mills AL, Stetzenbach LD). American Society for Microbiology Press, Washington, DC, pp. 69-79.

Reguera G, McCarthy KD, Mehta T, Nicoll JS, Tuominen MT, Lovley DR (2005) Extracellular electron transfer via microbial nanowires. Nature 435, 1098-1101. 
Reynolds ES (1963) The use of lead citrate at high $\mathrm{pH}$ as an electronopaque stain in electron microscopy. The Journal of Cell Biology 17 , 208-212.

Roden EE, Zachara JM (1996) Microbial reduction of crystalline $\mathrm{Fe}(\mathrm{III})$ oxides: influence of oxide surface area and potential for cell growth. Environmental Science \& Technology 30, 16181628.

Ross DE, Brantley SL, Tien M (2009) Kinetic characterization of OmcA and MtrC, terminal reductases involved in respiratory electron transfer for dissimilatory iron reduction in Shewanella oneidensis MR-1. Applied and Environmental Microbiology 75, $5218-5226$

Rosso KM, Smith DMA, Dupuis M (2003) An ab initio model of electron transport in hematite $\left(\alpha-\mathrm{Fe}_{2} \mathrm{O}_{3}\right)$ basal planes. The Journal of Chemical Physics 118, 6455-6466.

Shi L, Chen B, Wang Z, Elias DA, Mayer MU, Gorby YA, Ni S, Lower BH, Kennedy DW, Wunschel DS, Mottaz HM, Marshall MJ, Hill EA, Beliaev AS, Zachara JM, Fredrickson JK, Squier TC (2006) Isolation of a high-affinity functional protein complex between OmcA and MtrC: two outer membrane decaheme $c$-type cytochromes of Shewanella oneidensis MR-1. Journal of Bacteriology 188, 4705-4714.

Shi L, Squier TC, Zachara JM, Fredrickson JK (2007) Respiration of metal (hydr)oxides by Shewanella and Geobacter: a key role for multihaem $c$-type cytochromes. Molecular Microbiology 65, 12-20.

Shi L, Deng S, Marshall MJ, Wang Z, Kennedy DW, Dohnalkova AC, Mottaz HM, Hill EA, Gorby YA, Beliaev AS, Richardson DJ, Zachara JM, Fredrickson JK (2008) Direct involvement of type II secretion system in extracellular translocation of Shewanella oneidensis outer membrane cytochromes MtrC and OmcA. Journal of Bacteriology 190, 5512-5516.

Skepper JN (2000) Immunocytochemical strategies for electron microscopy: choice or compromise. Journal of Microscopy 199, 1-36.

Stookey LL (1970) Ferrozine - a new spectrophotometric reagent for iron. Analytical Chemistry 42, 779-781.

Suter D, Siffert C, Sulzberger B, Stumm W (1988) Catalytic dissoluion of iron(III)(hydr)oxides by oxalic acid in the presence of $\mathrm{Fe}(\mathrm{II})$. Die Naturwissenschaften 75, 571-573.

Taillefert M, Beckler JS, Carey E, Burns JL, Fennessey CM, DiChristina TJ (2007) Shewanella putrefaciens produces an $\mathrm{Fe}(\mathrm{III})$-solubilizing organic ligand during anaerobic respiration on insoluble $\mathrm{Fe}(\mathrm{III})$ oxides. Journal of Inorganic Biochemistry 101, 1760-1767.

Turick CE, Tisa LS, Caccavo F Jr (2002) Melanin production and use as a soluble electron shuttle for $\mathrm{Fe}$ (III) oxide reduction and as a terminal electron acceptor by Shewanella algae BrY. Applied and Environmental Microbiology 68, 24362444.

Turick C, Beliaev AS, Zakrajsek BA, Reardon CL, Lowy D, Poppy T, Maloney A, Ekechukwu A (2009) The role of 4-hydroxyphenylpyruvate dioxygenase in enhancement of solid-phase electron transfer by Shewanella oneidensis MR-1. FEMS Microbial Ecology 68, 223-225.
Wang Z, Liu C, Wang X, Marshall MJ, Zachara JM, Rosso KM, Dupuis M, Fredrickson JK, Heald S, Shi L (2008) Kinetics of reduction of $\mathrm{Fe}(\mathrm{III})$ complexes by outer membrane cytochromes MtrC and OmcA of Shewanella oneidensis MR-1. Applied and Environmental Microbiology 74, 6746-6755.

White JSJ, Leavens PB, Zanazzi PF (1986) Switzerite redefined as $\mathrm{Mn}_{3}\left(\mathrm{PO}_{4}\right)_{2} 7 \mathrm{H}_{2} \mathrm{O}$, and metaswitzerite, $\mathrm{Mn}_{3}\left(\mathrm{PO}_{4}\right)_{2} 4 \mathrm{H}_{2} \mathrm{O}$. The American Mineralogist 71, 1221-1223.

Wigginton NS, Rosso KM, Lower BH, Shi L, Hochella MF Jr (2007) Electron tunneling properties of outer-membrane decaheme cytochromes from Shewanella oneidensis. Geochimica et Cosmochimica Acta 71, 543-555.

Xiong Y, Shi L, Chen B, Mayer MU, Lower BH, Londer Y, Bose S, Hochella MF, Fredrickson JK, Squier TC (2006) High-affinity binding and direct electron transfer to solid metals by the Shewanella oneidensis MR-1 outer membrane $c$-type cytochrome OmcA. Journal of the American Chemical Society 128, 13978-13979.

Yan B, Wrenn BA, Basak S, Biswas P, Giammar DE (2008) Microbial reduction of $\mathrm{Fe}(\mathrm{III})$ in hematite nanoparticles by Geobacter sulfurreducens. Environmental Science and Technology 42, 6526-6531.

Zachara JM, Fredrickson JK, Li SM, Kennedy DW, Smith SC, Gassman PL (1998) Bacterial reduction of crystalline $\mathrm{Fe}^{3+}$ oxides in single phase suspensions and subsurface materials. The American Mineralogist 83, 1426-1443.

Zachara JM, Fredrickson JK, Smith SC, Gassman PL (2001) Solubilization of $\mathrm{Fe}$ (III) oxide-bound trace metals by a dissimilatory $\mathrm{Fe}(\mathrm{III})$ reducing bacterium. Geochimica et Cosmochimica Acta 65, 75-93.

Zachara JM, Kukkadapu RK, Fredrickson JK, Gorby YA, Smith SC (2002) Biomineralization of poorly crystalline $\mathrm{Fe}$ (III) oxides by dissimilatory metal reducing bacteria (DMRB). Geomicrobiology Journal 19, 179-207.

\section{SUPPORTING INFORMATION}

Additional Supporting Information may be found in the online version of this article:

Figure S1 Non-pseudocolored version of Fig. 1.

Figure S2 Non-pseudocolored version of Fig. 2.

Figure S3 Diffractograms of ferrihydrite incubated with $\Delta m t r C-\Delta o m c A$ or without cells at 11 days.

Please note: Wiley-Blackwell is not responsible for the content or functionality of any supporting materials supplied by the authors. Any queries (other than missing material) should be directed to the corresponding author for the article. 

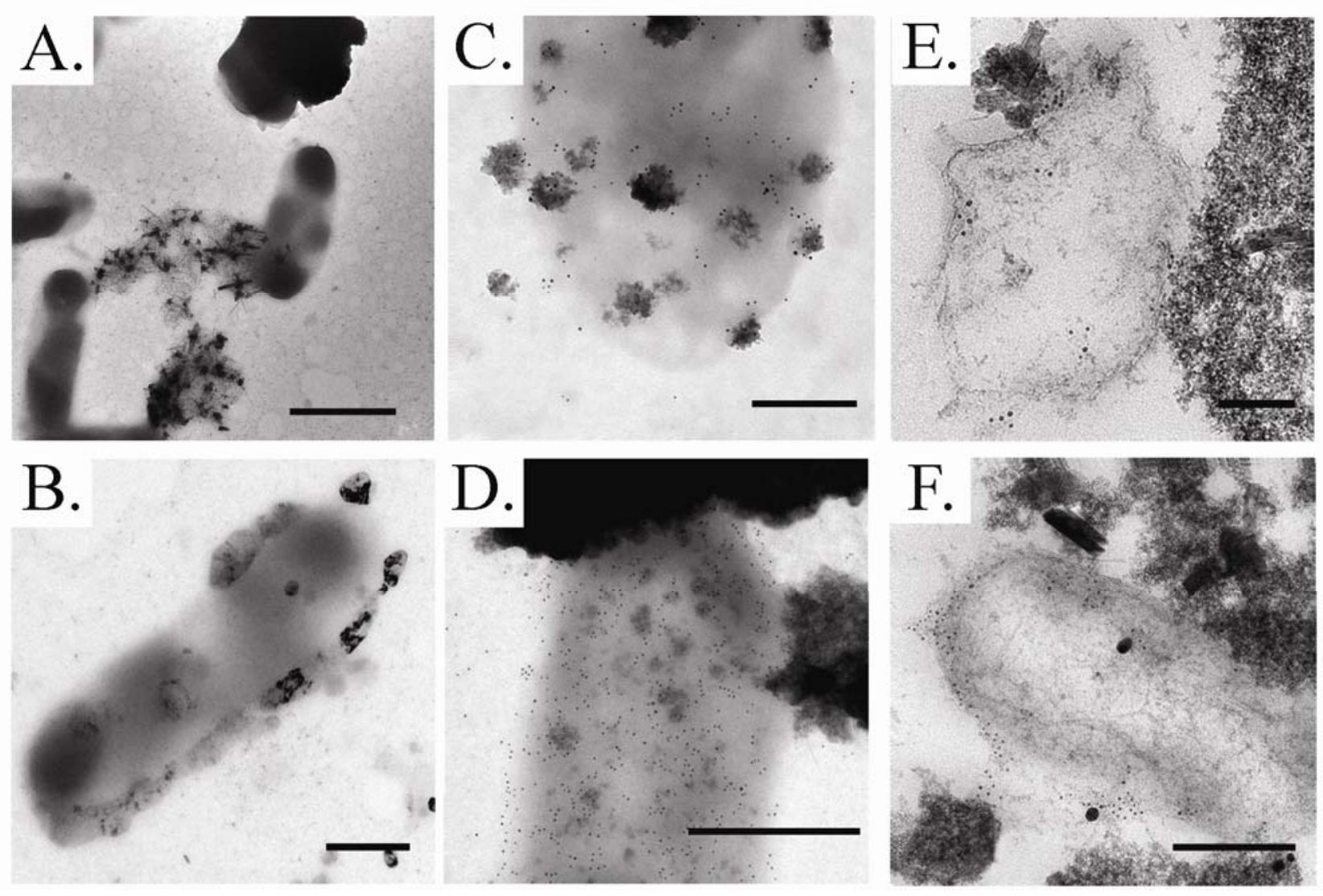

Fig. S1. Non-pseudocolored version of Fig. 1.

Reardon et al. Biotransformation of ferrihydrite by S. oneidensis MR-1 

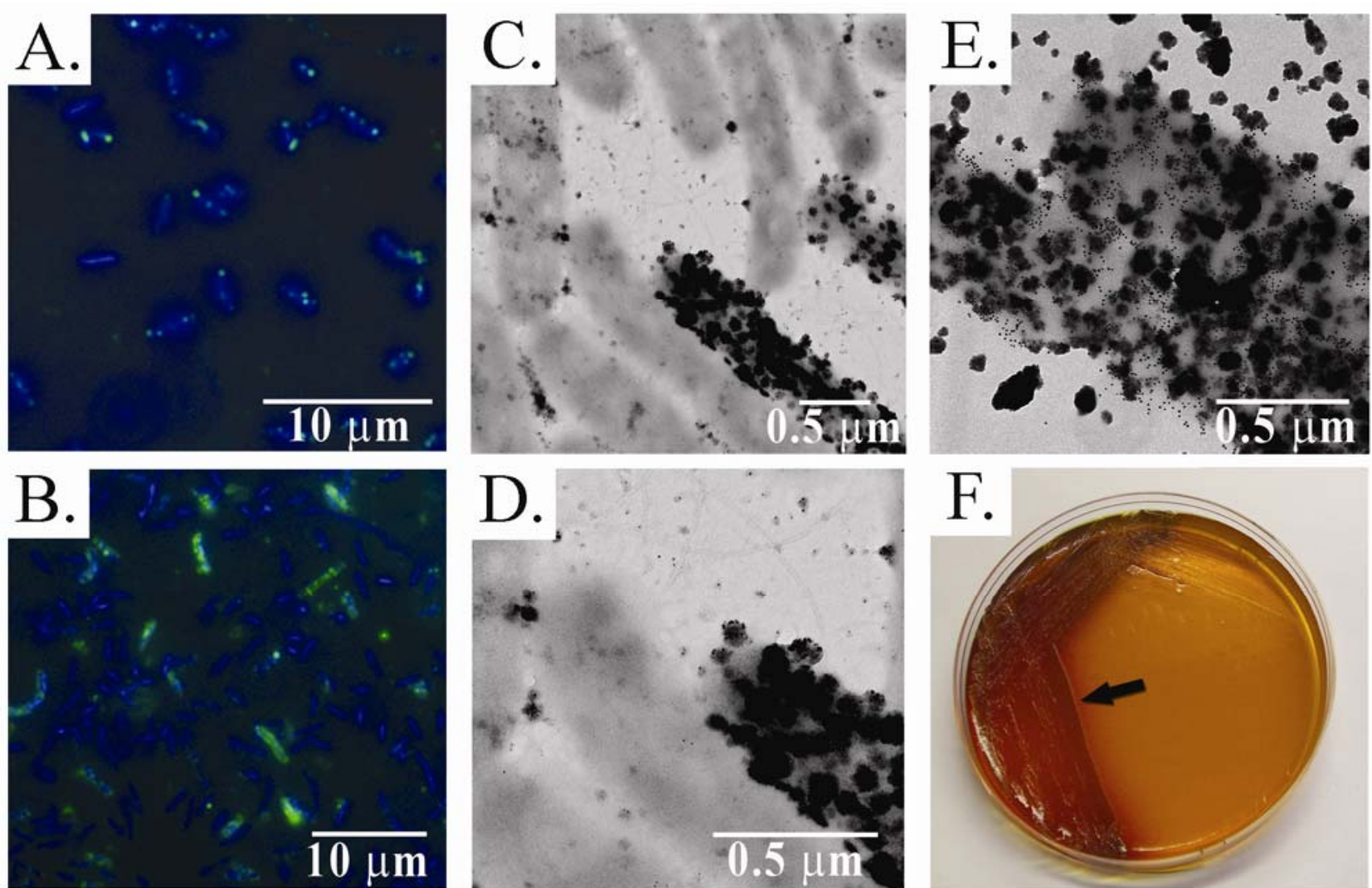

Fig. S2. Non-pseudocolored version of Fig. 2.

Reardon et al. Biotransformation of ferrihydrite by S. oneidensis MR-1 


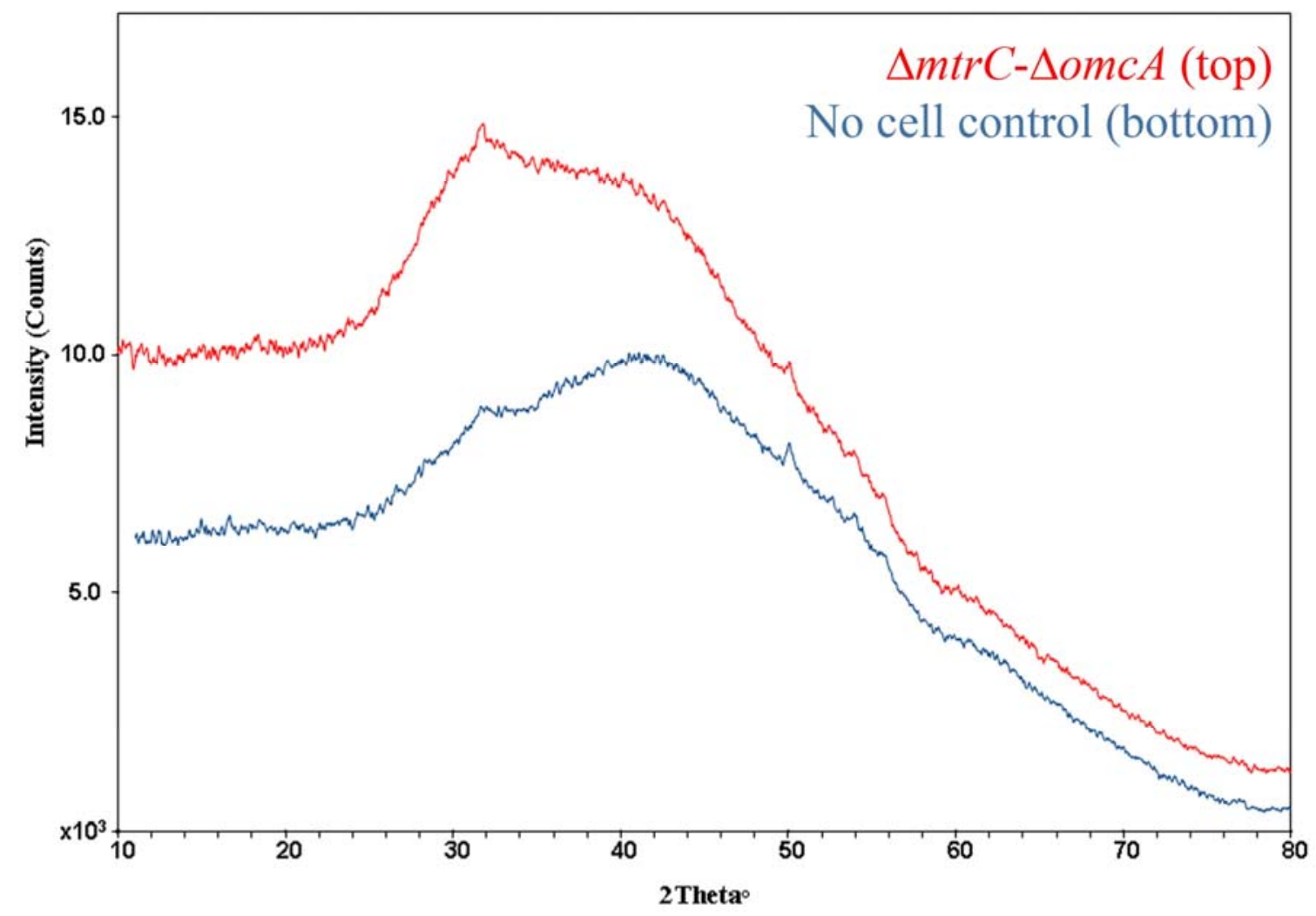

Fig. S3. Diffractograms of ferrihydrite incubated with $\triangle m$ trC- $\triangle$ omc $A$ or without cells at 11 days.

Reardon et al. Biotransformation of ferrihydrite by S. oneidensis MR-1 